Article

\title{
Effects on Carbon Sources and Sinks from Conversion of Over-Mature Forest to Major Secondary Forests and Korean Pine Plantation in Northeast China
}

\author{
Bin Wu ${ }^{1,2}{ }^{-}$, Changcheng Mu ${ }^{1,2, *}$, Jiaqi Zhao ${ }^{1}$, Xuejiao Zhou ${ }^{1}$ and Junhui Zhang ${ }^{3}$ \\ 1 Center for Ecological Research, Northeast Forestry University, No.26 Hexing Road Xiangfang District, \\ Harbin 150040, China \\ 2 Ministry of Education Key Laboratoty of Sustainable Forest Ecosystem Management, Northeast Forestry \\ University, No.26 Hexing Road Xiangfang District, Harbin 150040, China \\ 3 State Key Laboratory of Forest and Soil Ecology, Institute of Applied Ecology, Chinese Academy of Sciences, \\ No. 72 Wenhua Road Shenhe District, Shenyang 110016, China \\ * Correspondence: muccjs@nefu.edu.cn
}

Received: 4 July 2019; Accepted: 2 August 2019; Published: 5 August 2019

\begin{abstract}
The effects of replacing over-mature forest with secondary forests and plantations are significant for terrestrial ecosystem carbon (C) dynamics. However, the carbon balance and recovery time of this replacement process remain unclear. This study measured the fluxes of $\mathrm{CH}_{4}$ and $\mathrm{CO}_{2}$ in soils and the annual net $\mathrm{C}$ sequestration (ANCS) from seven ecosystems with different vegetation types (over-mature forest (OMF), Korean pine plantation (KPP), hardwood forest (HWF), Betula platyphylla forest (BPF), Populous davidiana forest (PDF), mixed deciduous forest (MDF), and Mongolian oak forest (MOF)) using the static chamber-gas chromatography method and the relative growth equation method. We examined the effects of environmental factors (e.g., air and soil temperature, soil volumetric water content (SVWC), soil $\mathrm{pH}$, nitrate nitrogen $\left(\mathrm{NO}_{3}{ }^{-}-\mathrm{N}\right)$, ammonium nitrogen $\left(\mathrm{NH}_{4}{ }^{+}-\mathrm{N}\right)$, and soil organic carbon (SOC)) on $\mathrm{CH}_{4}$ and $\mathrm{CO}_{2}$ fluxes at the Maoershan Ecosystem Research Station in Northeast China. The carbon source or sink of OMF, KPP, and five secondary forests (HWF, BPF, PDF, MDF, and MOF) were then evaluated based on net ecosystem $C$ balance. The results revealed that the mean annual $\mathrm{CH}_{4}$ fluxes varied between -0.046 and $-0.077 \mathrm{mg} \mathrm{m}^{-2} \mathrm{~h}^{-1}$. The mean annual absorption of $\mathrm{CH}_{4}$ in the secondary forests and OMF were respectively 1.09-1.67 times and 1.11 times higher than that of $\mathrm{KPP}\left(0.046 \mathrm{mg} \mathrm{m}^{-2} \mathrm{~h}^{-1}, p<0.05\right)$. The mean annual $\mathrm{CO}_{2}$ fluxes varied between 140.425 and $250.023 \mathrm{mg} \mathrm{m}^{-2} \mathrm{~h}^{-1}$. The $\mathrm{CO}_{2}$ fluxes in the secondary forests and KPP soils were respectively 1.33-1.78 times and 1.16 times higher than that of OMF $\left(140.425 \mathrm{mg} \mathrm{m}^{-2} \mathrm{~h}^{-1}\right.$, $p$ < 0.05). The $\mathrm{CH}_{4}$ and $\mathrm{CO}_{2}$ fluxes were mainly influenced by air and soil temperature, SVWC, soil $\mathrm{pH}, \mathrm{NO}_{3}{ }^{-}-\mathrm{N}, \mathrm{NH}_{4}{ }^{+}-\mathrm{N}$, and SOC in Northeast China. The ANCS of vegetation (3.41 $\pm 0.27-$ $6.26 \pm 0.75 \mathrm{t} \mathrm{C} \mathrm{ha}^{-1} \mathrm{y}^{-1}$ ) varied widely among different forest types: KPP had the largest ANCS $\left(6.26 \pm 0.75 \mathrm{t} \mathrm{C} \mathrm{ha}^{-1} \mathrm{y}^{-1}\right.$, which was higher than secondary forests and OMF by 1.20-1.84 times and 1.46 times, respectively, $p>0.05$ ). Carbon sources and sinks were significantly different among the seven types of vegetation: OMF and KPP were observed to be the greatest $C$ sinks, and secondary forests were shown to be the weakest carbon sinks or net $C$ sources in the study region.
\end{abstract}

Keywords: secondary forest; over-mature forest; Korean pine plantation; $\mathrm{CH}_{4}$ and $\mathrm{CO}_{2}$ fluxes; carbon sequestration; carbon sources/sinks; China

\section{Introduction}

Global climate changes caused by increasing major greenhouse gases $\left(\mathrm{CH}_{4}, \mathrm{CO}_{2}\right.$, and $\left.\mathrm{N}_{2} \mathrm{O}\right)$ in the atmosphere have aroused worldwide concerns [1]. Research has shown that the earth's response 
to greenhouse gases could be more sensitive than predicted, and global temperature could rise by more than $3{ }^{\circ} \mathrm{C}\left(1.8-4.0^{\circ} \mathrm{C}\right)$ by the end of the 21th century compared to the end of the 20th century [2]. Therefore, it is urgent to enhance the Carbon (C) sinks capacity of terrestrial ecosystems which could effectively mitigate the increased $\mathrm{CO}_{2}$ concentration in the atmosphere [3]. Forests have relatively stronger sustainability with the higher stability of structure and function in comparison with other terrestrial ecosystems (i.e., prairie ecosystem and desert ecosystem) [4]. They have stored approximately $40 \%$ and $80 \%$ of belowground and aboveground carbon in terrestrial ecosystems, respectively [5]. Therefore, the forest ecosystem has contributed significantly to global C sinks, and also has a positive effect on slowing or even reversing global warming [6,7].

In the past few decades, extensive research has focused on C cycling in forest ecosystems [8-10]. The preliminary assessments have shown that mature and growing forests generally remove carbon from the atmosphere at a rate of a few tons per hectare ( $t / h a)$ annually [11]. Carbon sinks were usually observed in boreal and hemiboreal forested areas $[12,13]$. Northern mid-latitude forests in the United States along with primary ponderosa pine forests in Oregon serve as a sink for atmospheric $\mathrm{CO}_{2}[14,15]$. However, several studies have shown that disturbances (such as harvest and fire) can transform mature forests from $C$ sinks to sources $[16,17]$. Artificial afforestation and natural restoration after deforestation or fire are two effective ways to restore forest carbon sinks, while the recovery process is significantly influenced by the recovery mode $[18,19]$. Plantations and secondary forests are two methods for recovering from the effects of anthropogenic disturbances, and related source or sink characteristics will be significantly altered as land-use changes [20]; as such, the carbon balances of such regenerating forest have numerous uncertainties [21]. For instance, several commercial plantations have been observed to be net $C$ sinks in the eastern United States [22,23]. A young ponderosa pine forest, which replaced an old-growth ponderosa pine forest, was shown to be a source of $C$ to the atmosphere [15]. There is also uncertainty about the length of time required for the $C$ balance recovery. For example, it took decades to recover the sink statuses in Siberia [16,17], the United States [15,24], and Europe [25] due to a wide range of emission rates. Net Primary Productivity (NPP) can take decades to exceed heterotrophic respiration in the boreal forest [26], and it took 20-30 years for Pacific Northwest regenerating coniferous forests to convert $\mathrm{C}$ source into net atmospheric $\mathrm{CO}_{2}$ sinks following the disturbance of forest regeneration [27]. Simulations have indicated it could take between 50 and 100 years for regrowth to restore $C$ sinks after a stand-replacing disturbance caused by a clearcut or fire [15]. Although this is influenced by forest management as far as $C$ sequestration, the amount of time required for temperate secondary forests and plantations to convert carbon sources into forest sinks remains unclear.

Forestry practices may not only affect $C$ sequestration but may also change soil respiration $\left(R_{S}\right)$ [28]. As the structure and function of a forest ecosystem could be altered after the replacement of the over-mature forests by secondary forests and plantations [29], forest conversion has shown complex and changeable effects on $R_{S}$ [30]. An estimate based on limited data has shown that the conversion of natural forest to secondary forests and plantations has led to reduced $\mathrm{R}_{\mathrm{S}}$ by $32 \%$ and $46 \%-48 \%$, respectively [31], while a significant increase in $\mathrm{CO}_{2}$ emission was observed by stand-replacing from secondary forest to plantations [32]. However, the environmental changes (soil temperatures, soil organic material, etc.) caused by disturbance have been observed to decrease [33], increase [34,35], or have no effect on soil heterotrophic respiration rates [36,37]. Additionally, some evidence has shown that carbon emissions can be gradually restored to the state of native vegetation using the secondary succession process; however, significant differences were observed in its recovery time in the results among these researchers. It took 30 years for $\mathrm{CH}_{4}$ emissions to be restored to forest level after conversion from pasture to forest in Costa Rica and Indonesia [38,39], 40 years in Switzerland [40], and 100 years in Denmark [41]. The phenomenon was caused by various factors (such as vegetation types and composition, climate conditions, and the activities of microbial enzymes, and so on) [42]. Therefore, a comprehensive study should be conducted on C balance based on NPP and $R_{S}$ at the 
ecosystem level of the over-mature forest, plantations, and secondary forests; this type of study is greatly needed in the temperate region of Asia.

Temperate forest in Northeast China is the largest temperate mixed forest in Asia. These forests have an important impact on the national $\mathrm{C}$ balance due to recent changes in land use including large standing tree volume and forested area [43,44], which account for $34.5 \%$ and $35.3 \%$ of the whole nation, respectively [30]. Due to the disturbance of human activities, secondary forests, which were developed due to the degradation of over-mature forest, have become the principal source of the current forest resources in China [45]. Therefore, the influence of secondary forests and plantations on C balance should be explored further to assist researchers in understanding their potential effects on climatic variation [46]. The specific objectives of the present study are twofold: (1) quantify the C emissions $\left(\mathrm{CH}_{4}\right.$ and $\left.\mathrm{CO}_{2}\right)$ from soil heterotrophic respiration, vegetation NPP, and net carbon sequestration of over-mature forest, Korean pine plantation, and five major natural secondary forests; and (2) evaluate the effects of replacement of over-mature forest by Korean pine plantation and secondary forests on C sources and sinks of temperate forests at the Maoershan Ecosystem Research Station in Northeast China. Our results could be critical for estimating regional and national $C$ sinks of forests and provide the basis for forest management guidelines.

\section{Materials and Methods}

\subsection{Study Site and Plot Layout}

The research presented in this paper is an experiment that was conducted at the Maoershan Ecosystem Research Station of Northeast Forestry University, Heilongjiang Province, Northeast China $\left(127^{\circ} 30^{\prime}-34^{\prime} \mathrm{E}, 45^{\circ} 20^{\prime}-25^{\prime} \mathrm{N}\right)$. This region represents typical forest types and landscapes with an average altitude of $300 \mathrm{~m}$ above the mean sea level in Northeast China. The study area is characterized by a continental monsoon climate in the north temperate zone with a mean annual temperature of $2.8^{\circ} \mathrm{C}$, and mean minimum and maximum air temperatures are -21.5 and $32.0^{\circ} \mathrm{C}$, respectively [47]. Annual precipitation ranges from 600 to $800 \mathrm{~mm}$, of which $80 \%$ falls in July and August. The parent material is granite bedrock with dark brown forest soil. Early frost occurs in September, late frost in May, and the frost-free period ranges from 120 to 140 days [48].

Korean pine is the dominant species in primary Chinese temperate forests and is mixed with such deciduous species as Quercus spp., Populus spp., and Betula spp., etc [44]. Since the turn of the 20th century, China's over-mature forest has been harvested on a large scale for industrial use and replaced by secondary forests and plantations [49]. A representative land-use sequence was selected for the present research in this region, including an over-mature mixed-broadleaved Korean pine forest, five major secondary forests, and a Korean pine plantation. The over-mature forest located at the top of a mountain was an over-mature forest that had never been damaged or disturbed by human activities. The five secondary forests were regenerated naturally following the harvest of the over-mature mixed-broadleaved Korean pine forest between 1949 and 1953. The Korean pine plantation was also converted from the over-mature forest by reforestation in 1964 . The above seven forest types had the same homogeneous substrate and original vegetation in history. The over-mature forest and six restored forests were all in the natural growth state without human disturbance or fertilization. They had a similar regional climate and topography, with slopes ranging from $7^{\circ}$ to $23^{\circ}$. Seven forest types were distributed under different site conditions: over-mature forest at moist fertile gentle upper slopes, Mongolian oak forest at arid infertile steep upper slopes, mixed deciduous forest and Populus davidiana forest at well-drained fertile gentle mid-slopes, Betula platyphylla forest and Korean pine plantation at well-drained fertile gentle toe slopes, and hardwood forest at moist fertile gentle toe slopes [48]. The basic characteristics of these forest types are summarized in Table 1. 
Table 1. Characteristics of stands from which sample trees were harvested ${ }^{\mathrm{a}}$.

\begin{tabular}{|c|c|c|c|c|c|c|c|}
\hline \multirow{2}{*}{$\begin{array}{l}\text { Forest } \\
\text { Type }\end{array}$} & \multirow{2}{*}{$\begin{array}{l}\text { Age } \\
\text { (Years) }\end{array}$} & \multirow{2}{*}{$\begin{array}{l}\text { Main Species Composition } \\
\text { b (Dominant Species) }\end{array}$} & \multirow{2}{*}{ Land-use History } & \multirow{2}{*}{$\begin{array}{l}\text { Density } \\
\left(\text { Trees ha } h^{-1}\right)\end{array}$} & \multirow{2}{*}{ BA $\left(m^{2} h a^{-1}\right)$} & \multicolumn{2}{|c|}{ DBH (cm) } \\
\hline & & & & & & Mean & Range \\
\hline OMF & $>150$ & $(8), 9,2,3,10,11,12,13,14$ & Natural forest & 789 & 54.6 & 25.3 & $4.0-69.1$ \\
\hline KPP & 51 & (8), $6,3,9,5,7,6$ & Reforestation in 1965 & 2111 & 42.1 & 15.0 & $3.9-34.4$ \\
\hline HWF & 60 & $(4),(3), 2,(7)$ & $\begin{array}{l}\text { Natural regeneration } \\
\text { after clearcutting in } 1955\end{array}$ & 1578 & 26.2 & 10.1 & $1.6-50.3$ \\
\hline BPF & 65 & (6), $15,12,17,18$ & $\begin{array}{l}\text { Natural regeneration } \\
\text { after clearcutting in } 1950\end{array}$ & 3022 & 25.4 & 7.4 & $1.4-34.8$ \\
\hline PDF & 65 & (6), (5), 7, 4, 3, 2 & $\begin{array}{l}\text { Natural regeneration } \\
\text { after clearcutting in } 1950\end{array}$ & 1833 & 34.1 & 12.1 & $1.6-49.4$ \\
\hline MDF & 65 & $2,7,4,3,5,6$ & $\begin{array}{l}\text { Natural regeneration } \\
\text { after clearcutting in } 1950\end{array}$ & 2022 & 34.8 & 11.3 & $1.9-49.6$ \\
\hline MOF & 66 & (1) $, 2,3,4,5,6$ & $\begin{array}{l}\text { Natural regeneration } \\
\text { after clearcutting in } 1949\end{array}$ & 1511 & 36.6 & 13.7 & $2.0-55.4$ \\
\hline
\end{tabular}

a Note: BA stands for the basal area; DBH for diameter at breast height; OMF for the over-mature forest; KPP for Korean pine plantation; HWF for hardwood forest; BPF for Betula platyphylla forest; PDF for Populus davidiana forest; MDF for the mixed deciduous forest; MOF for Mongolian oak forest. HWF, BPF, PDF, MDF, and MOF were five major secondary forests. ${ }^{b}$ (1), Quercus mongolica Fisch.; (2), Tilia amurensis Rupr.; (3), Fraxinus mandshurica Rupr.; (4), Phellodendron amurense Rupr.; (5), Populus davidiana Dode.; (6), Betula platyphylla Suk.; (7), Juglans mandshurica Maxim.; (8), Pinus koraiensis Sieb. et Zucc.; (9), Betula costata Trautv. (10), Acer ukurunduense Trautv. et Mey; (11), Abies nephrolepis (Trautv.) Maxim; (12), Ulmus laciniata (Trautv.) Mayr; (13), Acer tegmentosum Maxim; (14), Acer mono Maxim; (15), Larix gmelinii Rupr.; (16), Picea koraiensis Nakai; (17), Ulmus japonica (Rehd.) Sarg; (18), Alnus sibirica Fisch. ex Turcz.

The experiment was designed as a randomized complete block with three randomly selected sites in each forest type [50]. The three sites were approximately $0.5 \mathrm{~km}$ apart, and each site was approximately 0.06 ha $(20 \times 30 \mathrm{~m})$ in size. A comprehensive survey of soil and vegetation was conducted at the end of April 2015 to ensure the comparability (e.g., similar basic landform type in low mountain and hilly regions with an average slope of $10^{\circ}-15^{\circ}$; the soil is dark brown forest soil) of the soil sampling plots. Three static chambers were randomly placed in each forest type.

\subsection{Study Measurements}

\subsubsection{Carbon Sequestration and NPP}

Based on significant differences in climate conditions and forest growth, annual experimental data were organized into six periods; Spring: March to May; Summer: June to August; Fall: September to November; Winter: December to February (the following year); Growing season: early May to late October; and Non-growing season: early November to mid-to-late April (the following year).

The vegetation at the Maoershan Ecosystem Research Station of Northeast Forestry University was investigated in 2015. For arborous plants, the diameter at breast height (DBH) was measured with a caliper and recorded before and after the growing season in 2015. Species of both living and dead arborous trees were also recorded. The annual net primary productivity of each tree in 21 plots was determined from the difference between the two DBH measurements using allometric equations [48]. Carbon sequestration was calculated from annual net primary productivity estimates and $C$ concentration which were determined previously from a destructive sampling of biomass components for the studied arborous species within the Maoershan Ecosystem Research Station [51].

Shrubby and herbaceous plants (i.e., herbs, mosses, and grasses) were surveyed in five $5 \times 5 \mathrm{~m}$ and $101 \times 1 \mathrm{~m}$ subplots within each of the 21 fixed plots. Within these temporary plots, specimens were clipped at ground level and all species of shrubby and herbaceous plants (underground and aboveground) were collected and measured (measuring the fresh weight of plant samples). All the plant samples were dried at $70{ }^{\circ} \mathrm{C}$ for $24 \mathrm{~h}$. The samples were then weighed, and the water content was calculated. Finally, the dry plant biomass of the shrubby and herbaceous layers was obtained. The biomass of the shrubby layer divided by its average age ( 5 years) provided the annual net primary production of the shrubby layer. The annual biomass of the herbaceous layer was calculated by the sum of the annual underground biomass (annual new roots near the stem and lighter in color) and aboveground biomass (all the parts on the ground) in each of the 21 fixed plots. As the growing season 
was relatively short, only one sampling period was needed [52], and the peak standing biomass was the estimated aboveground herbaceous biomass at the end of the growing season [53].

Plant samples (stem, root, branch, and foliage of arborous plants; root, branch, and foliage of shrubby plants; aboveground stem, aboveground foliage, and underground root of herbaceous plants) were dried at $70{ }^{\circ} \mathrm{C}$ for $24 \mathrm{~h}$, weighed, and ground (in a Taisete mill with a 40 -mesh screen; $0.85 \mathrm{~mm}$ mesh), and C concentration of subsamples were analyzed by a Multi CN 3100 analyzer (Analytik Jena AG, Jena, Germany).

The product of the annual net primary productivity at respective vegetation layers (arborous layer, shrubby layer, and herbaceous layer) multiplied by the corresponding carbon concentrations resulted in the annual net carbon sequestration. The sum of the annual net carbon sequestration at the three vegetation layers was the total annual net carbon sequestration of all vegetation layers.

\subsubsection{Soil Gas Fluxes}

Soil gas fluxes were measured using the static chamber-gas chromatography method. The static chamber was made of a stainless-steel square box consisting of two parts, the removable box (without a bottom, $0.5 \times 0.5 \times 0.5 \mathrm{~m}$ ) and a fixed understructure (without a top, $0.5 \times 0.5 \times 0.2 \mathrm{~m}$ ) [54]. By using stainless-steel channels, the fixed understructure remained in place for the duration of the year-long sample collections. The channels were inserted $10 \mathrm{~cm}$ into the soil and filled with water to make the system air-tight [55], and sticky tape and snow were used to maintain the seal in winter. The removable box was inserted directly into the understructure during sample collection. Before sample collection, it had to be determined that no vegetation was present in the fixed understructure. Two battery-operated fans on the top of each chamber $(10 \mathrm{~cm}$ in diameter) were used to circulate the air inside the chamber when it was closed [50,55]. Two holes of $2 \mathrm{~cm}$ in diameter were made on the top of each chamber and were plugged with two rubber stoppers. One hole served as a sampling port, and the other was used to insert the digital thermometer probe. The electrical cord for the fan also passed through the top of the chamber, and the holes were sealed with silica gel [56]. Thermal foam insulation material was fastened to the exterior surface of the removable box to reduce the fluctuation of temperature in the removable box.

Soil gas fluxes were measured three times per month from May 2015 through April 2016, generally between 08:00 a.m. and 11:30 a.m. local time [57]. For $\mathrm{CH}_{4}$ and $\mathrm{CO}_{2}$, gas samples (50 mL each) were collected every $10 \mathrm{~min}$ using $50-\mathrm{mL}$ plastic syringes which were made air tight with a three-way stopcock: four 50-mL samples of the air from the chambers were withdrawn at intervals of $0,10,20$, and $30 \mathrm{~min}$ after closing the chamber [58]. After drawing the samples, the air in the syringes was transferred to previously evacuated and sealed reservoir bags, and was then brought to the laboratory for analysis. The headspace volume and air temperature inside the chamber were recorded to calculate the flux of $\mathrm{CH}_{4}$ and $\mathrm{CO}_{2}$ [55]. The collecting gas samples from inside the chambers and the monitoring of environmental factors (air temperature, as well as moisture and soil temperature at $0-40 \mathrm{~cm}$ below the soil surface) in each chamber were collected simultaneously. The collected gas samples were taken to the laboratory and analyzed for $\mathrm{CH}_{4}$ and $\mathrm{CO}_{2}$ within $24 \mathrm{~h}$ using a gas chromatograph (Agilent 7890A, Agilent Co., Santa Clara, CA, USA). Sample sets were rejected unless they yielded a linear regression value of $\mathrm{r}^{2}$ greater than 0.9 for $\mathrm{CH}_{4}$ and $\mathrm{CO}_{2}$ [59].

\subsubsection{Soil Properties Analysis}

Over one collection year, after soil gas collection at the end of every month, the surface litter beside each chamber location was removed, and a soil core of approximately $5 \mathrm{~cm}$ in diameter and $40 \mathrm{~cm}$ in length was also collected. After collection, soil samples were immediately transported in an insulated cooler to the laboratory and stored at $+4{ }^{\circ} \mathrm{C}$ before analysis [57]. The nitrate nitrogen $\left(\mathrm{NO}_{3}-\mathrm{N}\right)$ and ammonium nitrogen $\left(\mathrm{NH}_{4}{ }^{+}-\mathrm{N}\right)$ of the soil were extracted with a $2 \mathrm{M} \mathrm{KCl}$ solution (soil: solution, 1:5) and then filtered through a $0.45 \mu \mathrm{m}$ filter. The extracted solutions were measured by an AA3 Continuous Flow Analytical System. The collected soils (selecting a portion of collected soils from 
the experimental area) were sieved to $2 \mathrm{~mm}$. An aliquot (approximately $10 \mathrm{~g}$ ) of dried soil samples was used to measure soil $\mathrm{pH}$. Soil $\mathrm{pH}$ was determined in suspensions composed of a 1:5 ratio of soil to water with a PHS-3S pH meter [50]. Air and soil temperature were measured using digital thermometers beside each chamber location. The soil temperature measure had eight different depths down from the layers: $0,5,10,15,20,25,30$, and $40 \mathrm{~cm}$. Soil volumetric water content $\left(\mathrm{cm}^{3} \mathrm{H}_{2} \mathrm{O} \mathrm{cm}^{-3}\right.$ soil) was measured using a portable soil moisture tester (HS2, USA), which consisted of a soil moisture sensor and a handheld display. Soil organic carbon was analyzed using a multi-N/C 2100 analyzer (Analytik Jena AG, Jena, Germany).

\subsubsection{Carbon Source and Sink Analysis}

In order to determine the amount of carbon source and sink in over-mature forest, secondary forests, and Korean pine plantations in Northeast China, an evaluation was conducted based on annual net ecosystem carbon balance between May 2015 and May 2016 (the difference between the annual net carbon sequestration and the carbon emissions from soil heterotrophic respiration). It should be noted that throughout the research presented in this paper, carbon sinks are given a positive sign and carbon sources are given a negative sign.

\subsection{Calculation and Statistical Analysis}

Results are expressed as means with standard errors. Annual net primary productivity and annual net carbon sequestration, $\mathrm{CH}_{4}$ and $\mathrm{CO}_{2}$ fluxes, air and soil temperature, soil volumetric water content and $\mathrm{pH}$, soil $\mathrm{NO}_{3}{ }^{-}-\mathrm{N}$ and $\mathrm{NH}_{4}{ }^{+}-\mathrm{N}$, and soil organic carbon (SOC) for each treatment were calculated by averaging the three replicates for each sampling. The normality of distribution of all the experimental data was examined before the repeated measures using the Shapiro-Wilk's test. The difference in $\mathrm{CH}_{4}$ and $\mathrm{CO}_{2}$ fluxes in different seasons and vegetation types were determined by one-way analyses of variance (LSD; $p<0.05)$; Pearson's correlation coefficient $(\mathrm{r})$ was conducted to assess the correlation between environmental factors and $\mathrm{CH}_{4}$ and $\mathrm{CO}_{2}$ fluxes across seasons; stepwise multiple linear regression was developed to quantify the response of the environmental variables to $\mathrm{CH}_{4}$ and $\mathrm{CO}_{2}$ fluxes in seven forest types. All data analyses were carried out using SPSS Statistics 17.0.

\section{Results}

\subsection{Soil Properties}

The annual average air temperature decreased in the following order: Mongolian oak forest (MOF) $\left(6.93 \pm 0.05^{\circ} \mathrm{C}\right)>$ over-mature forest $(\mathrm{OMF})\left(5.92 \pm 0.01^{\circ} \mathrm{C}\right)>$ Korean pine plantation $(\mathrm{KPP})(5.63 \pm 0.01$ $\left.{ }^{\circ} \mathrm{C}\right)>$ mixed deciduous forest (MDF) $\left(4.93 \pm 0.05^{\circ} \mathrm{C}\right)>$ Betula platyphylla forest $(\mathrm{BPF})\left(4.79 \pm 0.02^{\circ} \mathrm{C}\right)>$ Populous davidiana forest $(\mathrm{PDF})\left(4.05 \pm 0.21^{\circ} \mathrm{C}\right)>$ hardwood forest $(\mathrm{HWF})\left(3.44 \pm 0.16^{\circ} \mathrm{C}\right)$. As presented in Table 2, it can be observed that the annual average air temperature in OMF and KPP was higher than that of secondary forests (except for MOF) by $0.99-2.48^{\circ} \mathrm{C}$ and $0.70-2.19^{\circ} \mathrm{C}$. The annual average soil temperature varied from 4.17 to 7.20 along with the seven sites, and it was higher in OMF than that in secondary forests by $0.30-3.03{ }^{\circ} \mathrm{C}$ and in $\mathrm{KPP}$ by $2.78^{\circ} \mathrm{C}$. The annual average soil volumetric water content was $35.45 \%$ in OMF that was higher by $27.1 \%$ and $14.9 \%-48.0 \%$ than that in KPP and secondary forests (except for HWF). Soil pH ranged from 5.43 to 6.02 . The concentration of $\mathrm{NO}_{3}{ }^{-}-\mathrm{N}$ in KPP was $9.76 \mathrm{mg} \mathrm{kg}^{-1}$ which was significantly higher than that in OMF $\left(5.42 \mathrm{mg} \mathrm{kg}^{-1}\right)$ and secondary forests $\left(1.09-2.58 \mathrm{mg} \mathrm{kg}^{-1}\right.$ ) by $80.1 \%$ and $278.3 \%-795.4 \%$, and $\mathrm{NO}_{3}{ }^{-}-\mathrm{N}$ in OMF was higher than that of secondary forests by $110.1 \%-397.2 \%$. The concentration of $\mathrm{NH}_{4}{ }^{+}-\mathrm{N}$ in $\mathrm{KPP}\left(24.12 \mathrm{mg} \mathrm{kg}^{-1}\right)$ was significantly higher than that in OMF $\left(6.46 \mathrm{mg} \mathrm{kg}^{-1}\right)$ and secondary forests $\left(4.32-4.97 \mathrm{mg} \mathrm{kg}^{-1}\right)$ by $273.4 \%$ and $385.3 \%-458.3 \%$, and $\mathrm{NH}_{4}{ }^{+}-\mathrm{N}$ in OMF was higher than that in secondary forests by $30.0 \%-49.5 \%(p>0.05)$. Soil organic $C$ was $72.02,55.26$, and $48.42-96.37 \mathrm{~g} \mathrm{~kg}^{-1}$ in OMF, KPP, and secondary forests, respectively. SOC in HWF soils was also significantly higher than that in all the 
forest stands by $33.8 \%-99.0 \%$. It was significantly higher in OMF than that in KPP and PBF, and MOF by $30.3 \%, 38.6 \%$, and $48.7 \%$.

Table 2. Physico-chemical properties of experimental sites. Data are expressed as mean $\pm \mathrm{SE}, n=12$.

\begin{tabular}{|c|c|c|c|c|c|c|c|}
\hline Properties & OMF & KPP & HWF & BPF & PDF & MDF & MOF \\
\hline $\operatorname{Air} \mathrm{T}\left({ }^{\circ} \mathrm{C}\right)$ & $5.92 \pm 0.01 \mathrm{~B}$ & $5.63 \pm 0.01 B$ & $3.44 \pm 0.16 \mathrm{E}$ & $4.79 \pm 0.02 C$ & $4.05 \pm 0.21 \mathrm{D}$ & $4.93 \pm 0.05 C$ & $6.93 \pm 0.05 \mathrm{~A}$ \\
\hline Soil $\mathrm{T}\left({ }^{\circ} \mathrm{C}\right)$ & $7.20 \pm 0.01 \mathrm{~A}$ & $4.42 \pm 0.01 \mathrm{E}$ & $4.17 \pm 0.06 \mathrm{~F}$ & $5.24 \pm 0.07 \mathrm{D}$ & $5.63 \pm 0.04 C$ & $5.17 \pm 0.15 \mathrm{D}$ & $6.90 \pm 0.11 B$ \\
\hline Soil moisture (\%) & $35.45 \pm 0.49 \mathrm{~A}$ & $27.90 \pm 0.12 C$ & $34.42 \pm 0.33 \mathrm{~A}$ & $26.58 \pm 0.32 \mathrm{D}$ & $30.84 \pm 0.41 \mathrm{~B}$ & $27.35 \pm 0.56 \mathrm{D}$ & $23.96 \pm 0.47 \mathrm{E}$ \\
\hline Soil pH & $5.51 \pm 0.04 \mathrm{C}$ & $6.02 \pm 0.03 \mathrm{~A}$ & $5.66 \pm 0.16 \mathrm{~B}$ & $5.43 \pm 0.05 \mathrm{BC}$ & $5.47 \pm 0.24 \mathrm{BC}$ & $5.53 \pm 0.06 \mathrm{~B}$ & $5.72 \pm 0.05 \mathrm{~B}$ \\
\hline $\mathrm{NO}_{3}-\mathrm{N}\left(\mathrm{mg} \mathrm{kg}^{-1}\right)$ & $5.42 \pm 0.35 \mathrm{~B}$ & $9.76 \pm 0.19 \mathrm{~A}$ & $2.58 \pm 0.26 \mathrm{C}$ & $1.09 \pm 0.13 \mathrm{D}$ & $2.22 \pm 0.42 \mathrm{C}$ & $2.18 \pm 0.35 C$ & $1.98 \pm 0.20 \mathrm{C}$ \\
\hline $\begin{array}{l}\mathrm{NH}_{4}^{+}-\mathrm{N} \\
\left(\mathrm{mg} \mathrm{kg}^{-1}\right)\end{array}$ & $6.46 \pm 0.48 B$ & $24.12 \pm 2.32 \mathrm{~A}$ & $4.97 \pm 0.07 \mathrm{~B}$ & $4.95 \pm 0.66 \mathrm{~B}$ & $4.60 \pm 1.69 \mathrm{~B}$ & $4.38 \pm 0.75 \mathrm{~B}$ & $4.32 \pm 0.19 \mathrm{~B}$ \\
\hline $\begin{array}{l}\text { Soil organic C } \\
\left(\mathrm{g} \mathrm{kg}^{-1}\right)\end{array}$ & $72.02 \pm 7.25 \mathrm{~B}$ & $55.26 \pm 1.08 \mathrm{CD}$ & $96.37 \pm 8.15 \mathrm{~A}$ & $51.96 \pm 3.32 \mathrm{D}$ & $\begin{array}{c}61.77 \pm \\
2.07 \mathrm{BCD}\end{array}$ & $69.92 \pm 4.52 \mathrm{BC}$ & $48.42 \pm 2.37 \mathrm{D}$ \\
\hline
\end{tabular}

Note: The different capital letters after numerical values indicate statistically significant differences within physico-chemical properties under different vegetation types $(p<0.05)$.

\subsection{Emission of GHGs}

\subsubsection{Methane Emission}

The fluxes of $\mathrm{CH}_{4}$ from seven forest types indicated a consistent net soil consumption of $\mathrm{CH}_{4}$ (i.e., negative $\mathrm{CH}_{4}$ flux) (Figure 1 and Table 3). The mean annual $\mathrm{CH}_{4}$ fluxes varied between -0.046 and $-0.077 \mathrm{mg} \mathrm{m}^{-2} \mathrm{~h}^{-1}$, and increased in the order of Korean pine plantation $\left(-0.046 \mathrm{mg} \mathrm{m}^{-2} \mathrm{~h}^{-1}\right)<$ over-mature forest $\left(-0.051 \mathrm{mg} \mathrm{m}^{-2} \mathrm{~h}^{-1}\right)<$ secondary forest (between -0.046 and- $-0.077 \mathrm{mg} \mathrm{m}^{-2} \mathrm{~h}^{-1}$ ) (Table 3), and significant differences were observed among the seven forest types $(p<0.05)$, of which, four secondary forest types (except for BPF) were significantly higher than that of KPP by $32.6 \%-67.4 \%$, and two secondary forest types (MDF and MOF) were $37.3 \%-51.0 \%$ greater than that of OMF (Figure 1 and Table 3). Among five secondary forests, the annual $\mathrm{CH}_{4}$ absorption in $\mathrm{MDF}$ was $24.2 \%-54.0 \%$ greater than that of the other three forests except for MOF (Table 3).

Seasonality had a significant impact on $\mathrm{CH}_{4}$ absorption: the maximum $\mathrm{CH}_{4}$ absorption value primarily occurred in May or June (summer), while little emission value was found in January in only a few types (winter) (Figure 1 and Table 3). Variation in $\mathrm{CH}_{4}$ absorption was pronounced during the growing season(-0.079-0.101 $\left.\mathrm{mg} \mathrm{m}^{-2} \mathrm{~h}^{-1}\right)$ compared to the non-growing season(-0.016-0.060 $\mathrm{mg}$ $\mathrm{m}^{-2} \mathrm{~h}^{-1}$ ) for all land-use types, of which the former was 1.7 to 5.5 times bigger than that of the latter (Table 3). No significant difference was observed in mean $\mathrm{CH}_{4}$ absorption values during the growing season, but significant differences were observed during the non-growing season. The mean $\mathrm{CH}_{4}$ absorption values in secondary forests (except for BPF) was significantly higher than that of KPP by $118.8 \%-275.0 \%$, and in MDF and MOF the absorption value was $74.2 \%$ and $93.5 \%$ greater than that of OMF, which in OMF was $93.8 \%$ greater than that of KPP during the growing season (Table 3). It was also found that the difference of the mean $\mathrm{CH}_{4}$ absorption during the non-growing season was the primary cause of the differences in absorption value of the mean annual $\mathrm{CH}_{4}$ among seven forest types. 


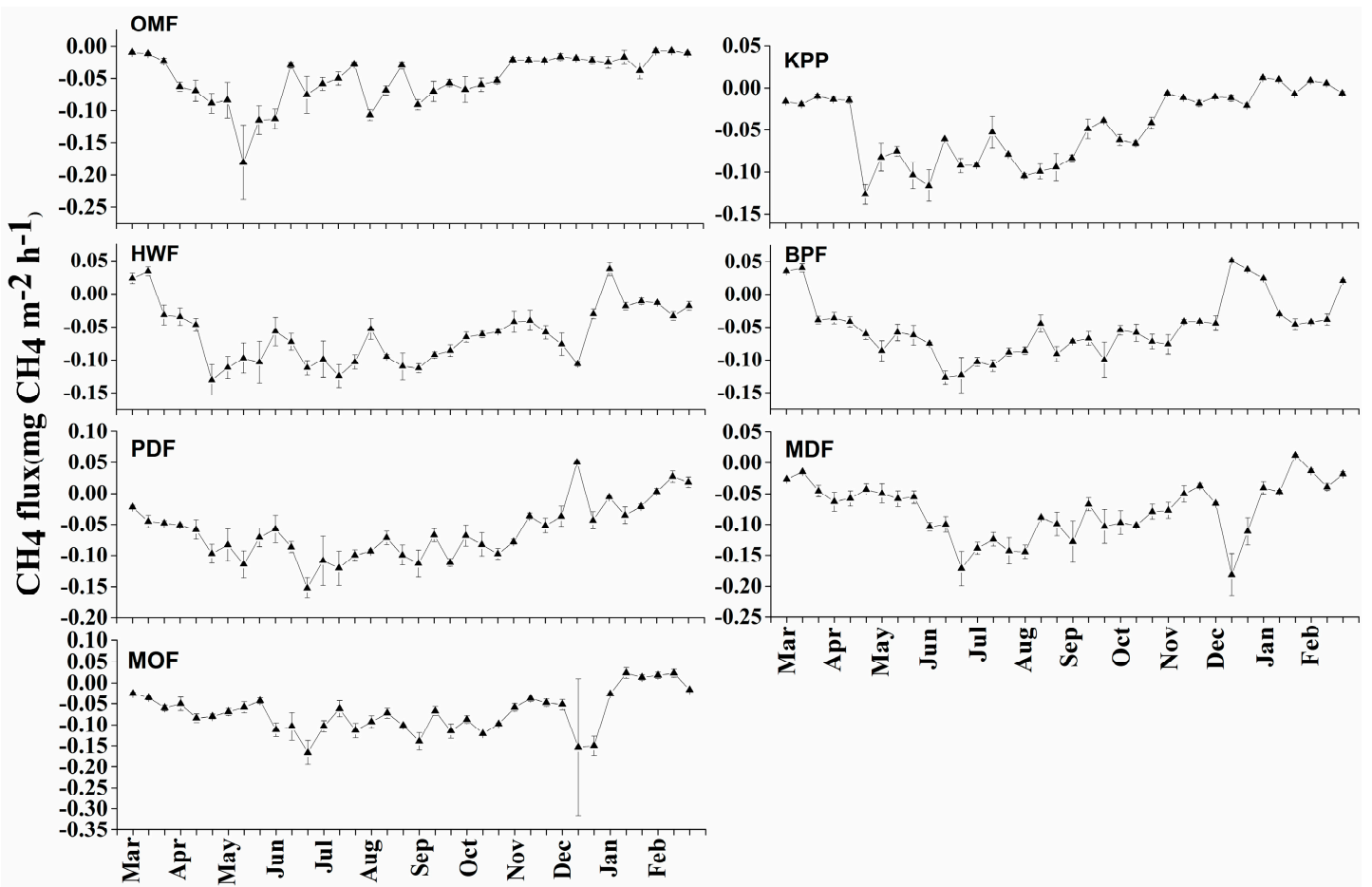

Figure 1. Temporal emission of methane from soil samples of seven forest types during May 2015 and April 2016.

Table 3. Methane fluxes $\left(\mathrm{mg} \mathrm{CH}_{4} \mathrm{~m}^{-2} \mathrm{~h}^{-1}\right)$ from the over-mature forest, Korean pine plantation, and five secondary forest soils at the Maoershan Ecosystem Research Station in Northeast China. Data are expressed as mean $\pm \mathrm{SE}, n=3$.

\begin{tabular}{|c|c|c|c|c|c|c|c|}
\hline \multirow{2}{*}{$\begin{array}{l}\text { Observe } \\
\text { Period }\end{array}$} & \multicolumn{7}{|c|}{ Vegetation Types } \\
\hline & OMF & KPP & HWF & BPF & PDF & MDF & MOF \\
\hline Spring & $-0.072 \pm 0.010 \mathrm{Db}$ & $-0.051 \pm 0.005 \mathrm{BCb}$ & $-0.053 \pm 0.003 \mathrm{BCb}$ & $-0.033 \pm 0.003 \mathrm{Ab}$ & $-0.067 \pm 0.003 \mathrm{CDb}$ & $-0.043 \pm 0.003 \mathrm{ABa}$ & $-0.053 \pm 0.003 \mathrm{BCab}$ \\
\hline Summer & & $088 \pm 0.008 \mathrm{ABC}$ & $-0.093 \pm 0.012 \mathrm{ABCc}$ & $-0.093 \pm 0.003 \mathrm{ABCd}$ & & & $15 \mathrm{BCc}$ \\
\hline Autumn & $-0.052 \pm 0.006 \mathrm{ABb}$ & $-0.042 \pm 0.003 \mathrm{Ab}$ & $-0.070 \pm 0.006 \mathrm{BCb}$ & $-0.063 \pm 0.003 \mathrm{BC} \mathrm{c}$ & $-0.080 \pm 0.010 \mathrm{Cbc}$ & $-0.080 \pm 0.006 \mathrm{Cb}$ & $-0.083 \pm 0.007 \mathrm{Cbc}$ \\
\hline Winter & $-0.018 \pm 0.003 \mathrm{ABCa}$ & $-0.002 \pm 0.001 \mathrm{Aa}$ & $-0.030 \pm 0.001 \mathrm{BCa}$ & $-0.007 \pm 0.003 \mathrm{ABa}$ & $-0.007 \pm 0.003 \mathrm{ABa}$ & $-0.057 \pm 0.009 \mathrm{Da}$ & $-0.037 \pm 0.019 \mathrm{CDa}$ \\
\hline Gs & $-0.079 \pm 0.006 \mathrm{Ab}$ & $-0.088 \pm 0.003 \mathrm{Ab}$ & $-0.098 \pm 0.007 \mathrm{Ab}$ & $-0.084 \pm 0.004 \mathrm{Ab}$ & $-0.096 \pm 0.011 \mathrm{Ab}$ & $-0.101 \pm 0.006 \mathrm{Ab}$ & $-0.092 \pm 0.011 \mathrm{Ab}$ \\
\hline Ngs & $-0.031 \pm 0.004 \mathrm{Ba}$ & $-0.016 \pm 0.001 \mathrm{Aa}$ & $-0.035 \pm 0.003 \mathrm{Ba}$ & $-0.026 \pm 0.001 \mathrm{ABa}$ & $-0.038 \pm 0.006 \mathrm{Ba}$ & $-0.060 \pm 0.005 \mathrm{Ca}$ & $-0.054 \pm 0.005 \mathrm{Ca}$ \\
\hline $\mathrm{Aa}$ & $-0.051 \pm 0.003 \mathrm{AB}$ & $-0.046 \pm 0.002 \mathrm{~A}$ & $-0.061 \pm 0.004 \mathrm{BC}$ & $-0.050 \pm 0.002 \mathrm{AB}$ & $-0.062 \pm 0.006 \mathrm{BC}$ & $-0.077 \pm 0.004 \mathrm{D}$ & $-0.070 \pm 0.006 \mathrm{CD}$ \\
\hline
\end{tabular}

Note: The different lowercase letters after numerical values indicate statistically significant differences within treatments among different seasons. The different capital letters after numerical values indicate statistically significant differences within seasons among different treatments. Abbreviations: Gs-Growing Season; Ngs—Non-growing Season; Aa-Annual average.

\subsubsection{Carbon Dioxide Emission}

A significant difference in the mean annual $\mathrm{CO}_{2}$ fluxes was observed from the seven forest types, which decreased in the following order: secondary forest (186.387-250.023 $\left.\mathrm{mg} \mathrm{m}^{-2} \mathrm{~h}^{-1}\right)>$ Korean pine plantation $\left(163.441 \mathrm{mg} \mathrm{m}^{-2} \mathrm{~h}^{-1}\right)>$ over-mature forest $\left(140.425 \mathrm{mg} \mathrm{m}^{-2} \mathrm{~h}^{-1}\right)$. Specifically, four secondary forests (except for HWF) averaged higher $\mathrm{CO}_{2}$ flux by $33.0 \%-53.0 \%$ compared with $\mathrm{KPP}$, and five secondary forests averaged higher $\mathrm{CO}_{2}$ flux by $32.7 \%-78.0 \%$ compared with OMF $(p<0.05)$ (Table 4). However, no significant difference was observed between OMF and KPP (the latter was higher than that of the former by $16.4 \%, p>0.05$ ). Among the five secondary forests, both MDF and PDF were $34.1 \%$ and $21.1 \%$ greater than that of HWF, respectively (Table 4 ).

There were clear seasonal dynamics apparent in the $\mathrm{CO}_{2}$ fluxes, which increased rapidly since the start of early spring; then the $\mathrm{CO}_{2}$ peak flux occurred in summer when the soil temperature was relatively high, and humidity was moderate. Figure 2 showed a trend of fluctuating downward during the late summer and fall, and the emissions were already low during winter when both soil temperature and moisture were low. The mean $\mathrm{CO}_{2}$ fluxes during the growing season $\left(299.579-492.280 \mathrm{mg} \mathrm{m}^{-2} \mathrm{~h}^{-1}\right)$ were 4.8 to 11.2 times bigger than that of the non-growing season (26.743-87.042 $\mathrm{mg} \mathrm{m}^{-2} \mathrm{~h}^{-1}$ ) (Table 4). 
The mean $\mathrm{CO}_{2}$ fluxes in four secondary forests (except for HWF) were significantly higher than that of KPP by $28.6 \%-50.7 \%$ and in OMF by $40.2 \%-64.3 \%$, respectively. No significant difference was observed in OMF and KPP. During the non-growing season, the four secondary forest types (except for HWF) were significantly higher than that of KPP by $52.2 \%-85.9 \%$, and five secondary forest types were $139.1 \%-225.5 \%$ greater than that of OMF, but no significant difference was observed between OMF and KPP. Table 4 shows that the difference of the mean $\mathrm{CO}_{2}$ fluxes during both growing and non-growing seasons was the primary cause of the differences in the mean annual $\mathrm{CO}_{2}$ emissions among seven forest types.

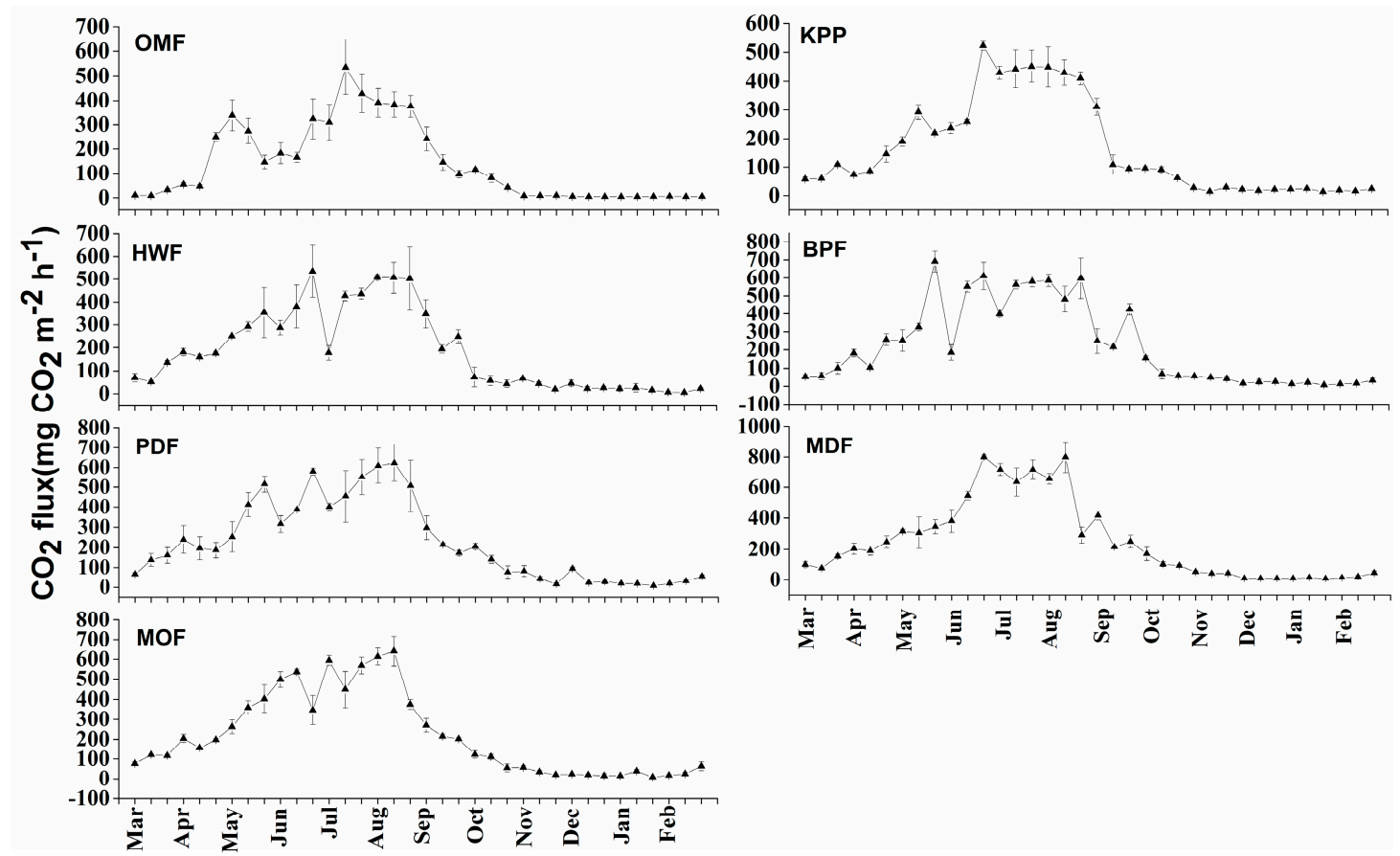

Figure 2. Temporal emission of carbon dioxide from soil samples of seven forest types during May 2015 and April 2016.

Table 4. Carbon dioxide fluxes $\left(\mathrm{mg} \mathrm{CO}_{2} \mathrm{~m}^{-2} \mathrm{~h}^{-1}\right)$ from the over-mature forest, Korean pine plantation, and five secondary forest soils at the Maoershan Ecosystem Research Station in Northeast China. Data are expressed as mean $\pm \mathrm{SE}, n=3$.

\begin{tabular}{|c|c|c|c|c|c|c|c|}
\hline \multirow{2}{*}{$\begin{array}{c}\text { Observe } \\
\text { Period }\end{array}$} & \multicolumn{7}{|c|}{ Vegetation Types } \\
\hline & OMF & KPP & HWF & BPF & PDF & MDF & MOF \\
\hline Spring & $129.295 \pm 14.521 \mathrm{Bb}$ & $137.162 \pm 5.692 \mathrm{Bb}$ & $185.272 \pm 17.789 \mathrm{ABb}$ & $224.517 \pm 12.656 \mathrm{Ab}$ & $240.538 \pm 33.223 \mathrm{Ab}$ & $215.354 \pm 29.795 \mathrm{Ab}$ & $210.625 \pm 14.015 \mathrm{Ab}$ \\
\hline Summer & $344.022 \pm 58.402 \mathrm{Ea}$ & $403.728 \pm 8.646 \mathrm{DEa}$ & $417.525 \pm 3.152 \mathrm{CDEa}$ & $505.714 \pm 21.556 \mathrm{BCa}$ & $491.544 \pm 22.390 \mathrm{BCDa}$ & $615.834 \pm 23.961 \mathrm{Aa}$ & $513.435 \pm 31.230 \mathrm{Ba}$ \\
\hline Winter & $5.003 \pm 0.418 \mathrm{Cc}$ & $20.063 \pm 0.816 \mathrm{Bd}$ & $21.297 \pm 6.254 \mathrm{Bd}$ & $19.283 \pm 2.307 \mathrm{Bd}$ & $32.750 \pm 1.515 \mathrm{Ad}$ & $15.347 \pm 2.192 \mathrm{BC}$ & $24.763 \pm 3.564 \mathrm{ABd}$ \\
\hline Gs & $299.579 \pm 47.196 \mathrm{Ca}$ & $326.703 \pm 6.949 \mathrm{Ca}$ & $357.814 \pm 6.843 \mathrm{BCa}$ & $435.952 \pm 8.252 \mathrm{ABa}$ & $420.000 \pm 21.039 \mathrm{ABa}$ & $492.280 \pm 23.938 \mathrm{Aa}$ & $421.820 \pm 26.689 \mathrm{ABa}$ \\
\hline Ngs & $26.743 \pm 2.048 \mathrm{Db}$ & $46.825 \pm 1.261 \mathrm{Cb}$ & $63.944 \pm 6.477 \mathrm{BCb}$ & $72.707 \pm 2.705 \mathrm{ABb}$ & $87.042 \pm 12.142 \mathrm{Ab}$ & $76.979 \pm 8.340 \mathrm{ABb}$ & $71.291 \pm 3.665 \mathrm{ABb}$ \\
\hline $\mathrm{Aa}$ & $140.425 \pm 20.629 \mathrm{D}$ & $163.441 \pm 3.610 \mathrm{CD}$ & $186.387 \pm 5.151 \mathrm{BC}$ & $224.057 \pm 2.277 \mathrm{AB}$ & $225.773 \pm 15.610 \mathrm{~A}$ & $250.023 \pm 14.472 \mathrm{~A}$ & $217.343 \pm 9.122 \mathrm{AB}$ \\
\hline
\end{tabular}

Note: The different lowercase letters after numerical values indicate statistically significant differences within treatments among different seasons. The different capital letters after numerical values indicate statistically significant differences within seasons among different treatments. Abbreviations: Gs-Growing Season; Ngs-Non-growing Season; Aa-Annual average.

\subsubsection{Key Soil Factors Affecting $\mathrm{CH}_{4}$ and $\mathrm{CO}_{2}$ Fluxes}

Correlation analysis of greenhouse gas with environmental temperature and soil volume water content for each land-use type is depicted in Table $5 . \mathrm{CH}_{4}$ fluxes were significantly negatively correlated with environmental temperature (air and soil temperature, $0-40 \mathrm{~cm}$ soil depth). $\mathrm{CH}_{4}$ fluxes from five secondary forests were significantly negatively correlated with soil volumetric water content (SVWC) at different soil depths. However, $\mathrm{CH}_{4}$ fluxes did not display any pronounced dependency on 
SVWC for OMF (Table 5). Note that $\mathrm{CH}_{4}$ fluxes from KPP were significantly negatively correlated with environmental temperature, but positively correlated with SVWC (Table 5).

$\mathrm{CO}_{2}$ fluxes, as measured from KPP, OMF, and secondary forests, were significantly positively correlated with air and soil temperature (0-40 cm soil depth) (Table 5). The results showed no correlation between $\mathrm{CO}_{2}$ fluxes and SVWC for OMF (Table 5). However, the $\mathrm{CO}_{2}$ emission in KPP was negatively correlated with the surface SVWC $(0-10 \mathrm{~cm}$ soil depth) and a significantly positive correlation was observed between $\mathrm{CO}_{2}$ fluxes from secondary forests except for $\mathrm{HWF}$, which showed a negative correlation $(15-40 \mathrm{~cm})$ (Table 5).

Table 5. Correlations between $\mathrm{CH}_{4}$ and $\mathrm{CO}_{2}$ fluxes and environmental temperature and soil volume water content in seven types of vegetation at the Maoershan Ecosystem Research Station in Northeast China.

\begin{tabular}{|c|c|c|c|c|c|c|c|c|c|}
\hline & & \multirow{2}{*}{$\begin{array}{c}\text { Soil } \\
\text { Layer/cm }\end{array}$} & \multicolumn{7}{|c|}{ Sample Site } \\
\hline & & & OMF & KPP & HWF & BPF & PDF & MDF & MOF \\
\hline \multirow{16}{*}{$\mathrm{CH}_{4}$} & \multirow{9}{*}{ temperature } & Air T & $-0.632 * *$ & $-0.791 * *$ & $-0.525^{* *}$ & $-0.629 * *$ & $-0.722 * *$ & $-0.375 *$ & $-0.419 *$ \\
\hline & & 0 & $-0.612 * *$ & $-0.855^{* *}$ & $-0.692 * *$ & $-0.732 * *$ & $-0.777^{* *}$ & $-0.590 * *$ & $-0.465^{* *}$ \\
\hline & & 5 & $-0.588^{* *}$ & $-0.840^{* *}$ & $-0.688^{* *}$ & $-0.725^{* *}$ & $-0.772 * *$ & $-0.592^{* *}$ & $-0.512^{* *}$ \\
\hline & & 10 & $-0.564^{* *}$ & $-0.822 * *$ & $-0.685^{* *}$ & $-0.730 * *$ & $-0.780 * *$ & $-0.611^{* *}$ & $-0.543^{* *}$ \\
\hline & & 15 & $-0.557^{* *}$ & $-0.817^{* *}$ & $-0.707^{* *}$ & $-0.727^{* *}$ & $-0.779 * *$ & $-0.630^{* *}$ & $-0.561^{* *}$ \\
\hline & & 20 & $-0.550 * *$ & $-0.803^{* *}$ & $-0.705^{* *}$ & $-0.727^{* *}$ & $-0.777^{* *}$ & $-0.651^{* *}$ & $-0.582 * *$ \\
\hline & & 25 & $-0.497^{* *}$ & $-0.789 * *$ & $-0.691 * *$ & $-0.725^{* *}$ & $-0.774^{* *}$ & $-0.662 * *$ & $-0.584^{* *}$ \\
\hline & & 30 & $-0.532 * *$ & $-0.777^{* *}$ & $-0.705^{* *}$ & $-0.726^{* *}$ & $-0.778 * *$ & $-0.667^{* *}$ & $-0.592^{* *}$ \\
\hline & & 40 & $-0.496^{* *}$ & $-0.747^{* *}$ & $-0.284^{* *}$ & $-0.723^{* *}$ & $-0.774^{* *}$ & $-0.682^{* *}$ & $-0.616^{* *}$ \\
\hline & \multirow{7}{*}{$\begin{array}{c}\text { soil volume } \\
\text { water content }\end{array}$} & 0 & $0.084^{\mathrm{ns}}$ & $0.769^{* *}$ & $-0.284^{\mathrm{ns}}$ & $-0.308^{\mathrm{ns}}$ & $-0.387^{*}$ & $0.077^{\mathrm{ns}}$ & $-0.349^{\mathrm{ns}}$ \\
\hline & & 5 & $0.007^{\mathrm{ns}}$ & $0.750 * *$ & $-0.404 *$ & $-0.456^{* *}$ & $-0.470 * *$ & $0.100^{\mathrm{ns}}$ & $-0414^{*}$ \\
\hline & & 10 & $0.056^{\mathrm{ns}}$ & $0.766^{* *}$ & $-0.402 *$ & $-0.503^{* *}$ & $-0.612^{* *}$ & $0.030^{\mathrm{ns}}$ & -0.452 * \\
\hline & & 15 & $0.048^{\mathrm{ns}}$ & $0.831^{* *}$ & $-0.598^{* *}$ & $-0.679 * *$ & $-0.738^{* *}$ & $-0.544^{* *}$ & $-0.513^{* *}$ \\
\hline & & 20 & $-0.191^{\mathrm{ns}}$ & $0.789 * *$ & $-0.601^{* *}$ & $-0.706^{* *}$ & $-0.763 * *$ & $-0.548^{* *}$ & $-0.521^{* *}$ \\
\hline & & 25 & $-0.284^{\mathrm{ns}}$ & $0.782 * *$ & $-0.618^{* *}$ & $-0.705^{* *}$ & $-0.766^{* *}$ & $-0.558^{* *}$ & $-0.529 * *$ \\
\hline & & 30 & $-0.200^{\mathrm{ns}}$ & $0.689 * *$ & $-0.616^{* *}$ & $-0.712 * *$ & $-0.776^{* *}$ & $-0.549^{* *}$ & $-0.515^{* *}$ \\
\hline \multirow{18}{*}{$\mathrm{CO}_{2}$} & \multirow{9}{*}{ temperature } & 40 & $-0.167^{\mathrm{ns}}$ & $0.622 * *$ & $-0.596^{* *}$ & $-0.705^{* *}$ & $-0.762 * *$ & $-0.536^{* *}$ & $-0.502^{* *}$ \\
\hline & & Air T & $0.799 * *$ & $0.780 * *$ & $0.817^{* *}$ & $0.791 * *$ & $0.827^{* *}$ & $0.826^{* *}$ & $0.847^{* *}$ \\
\hline & & 0 & $0.844^{* *}$ & $0.930 * *$ & $0.860 * *$ & $0.891 * *$ & $0.894^{* *}$ & $0.921 * *$ & $0.878^{* *}$ \\
\hline & & 5 & $0.898^{* *}$ & $0.939^{* *}$ & $0.877^{* *}$ & $0.892 * *$ & $0.912 * *$ & $0.914^{* *}$ & $0.886^{* *}$ \\
\hline & & 10 & $0.917^{* *}$ & $0.927^{* *}$ & $0.884^{* *}$ & $0.890 * *$ & $0.900 * *$ & $0.914^{* *}$ & $0.904^{* *}$ \\
\hline & & 15 & 0.920 ** & $0.932 * *$ & $0.887^{* *}$ & $0.885^{* *}$ & $0.899 * *$ & $0.905^{* *}$ & $0.906^{* *}$ \\
\hline & & 20 & $0.915^{* *}$ & $0.932 * *$ & $0.877^{* *}$ & $0.883^{* *}$ & $0.890 * *$ & $0.899^{* *}$ & $0.900 * *$ \\
\hline & & 25 & 0.820 ** & $0.922 * *$ & $0.879^{* *}$ & $0.879 * *$ & $0.887^{* *}$ & $0.895^{* *}$ & $0.899^{* *}$ \\
\hline & & 30 & $0.903 * *$ & $0.910 * *$ & $0.871^{* *}$ & $0.874 * *$ & $0.885^{* *}$ & $0.879^{* *}$ & $0.897^{* *}$ \\
\hline & \multirow{9}{*}{$\begin{array}{c}\text { soil volume } \\
\text { water content }\end{array}$} & 40 & $0.882^{* *}$ & $0.892^{* *}$ & $0.856^{* *}$ & $0.863^{* *}$ & $0.873^{* *}$ & $0.875^{* *}$ & $0.889^{* *}$ \\
\hline & & 0 & $-0.269^{\mathrm{ns}}$ & $-0.321^{\mathrm{ns}}$ & $0.318^{\mathrm{ns}}$ & 0.395 * & $0.591 * *$ & $0.116^{\mathrm{ns}}$ & $0.724 * *$ \\
\hline & & 5 & $-0.052^{\mathrm{ns}}$ & $-0.513 *$ & $0.175^{\mathrm{ns}}$ & $0.445^{*}$ & $0.677^{* *}$ & $0.132^{\mathrm{ns}}$ & $0.741^{* *}$ \\
\hline & & 10 & $-0.057^{\mathrm{ns}}$ & $-0.612 * *$ & $0.151^{\mathrm{ns}}$ & $0.482 * *$ & $0.652 * *$ & $0.303^{\mathrm{ns}}$ & $0.763^{* *}$ \\
\hline & & 15 & $-0.088^{\mathrm{ns}}$ & $-0.475^{\mathrm{ns}}$ & $-0.434^{*}$ & $0.685^{* *}$ & $0.761^{* *}$ & $0.905^{* *}$ & $0.826^{* *}$ \\
\hline & & 20 & $0.004^{\mathrm{ns}}$ & $-0.479^{\mathrm{ns}}$ & $-0.443 *$ & $0.689 * *$ & $0.748 * *$ & $0.912 * *$ & $0.814^{* *}$ \\
\hline & & 25 & $0.009^{\mathrm{ns}}$ & $-0.364^{\mathrm{ns}}$ & $-0.449^{*}$ & $0.706^{* *}$ & 0.734 ** & 0.912 ** & $0.811^{* *}$ \\
\hline & & 30 & $-0.222^{\mathrm{ns}}$ & $-0.352^{\mathrm{ns}}$ & $-0.434^{*}$ & $0.722 * *$ & $0.727^{* *}$ & $0.918^{* *}$ & $0.826^{* *}$ \\
\hline & & 40 & $-0.257^{\mathrm{ns}}$ & $-0.495^{*}$ & -0.421 * & $0.742 * *$ & 0.753 ** & $0.913^{* *}$ & $0.784^{* *}$ \\
\hline
\end{tabular}

Note: No significant relationships were observed between $\mathrm{CH}_{4}$ and $\mathrm{CO}_{2}$ fluxes and $\mathrm{pH}, \mathrm{NO}_{3}{ }^{-}-\mathrm{N}_{1} \mathrm{NH}_{4}{ }^{+}-\mathrm{N}$, and SOC. Therefore, the results are not listed in the table. ns: not significant; ${ }^{*} p<0.05$ level of significant; ${ }^{* *} p<0.01$ level of significant.

Stepwise multiple linear regression was used to identify the key environmental factors affecting $\mathrm{CH}_{4}$ and $\mathrm{CO}_{2}$ fluxes. The results indicated that air and soil temperature, $\mathrm{SVWC}, \mathrm{pH}, \mathrm{NO}_{3}{ }^{-}-\mathrm{N}_{1} \mathrm{NH}_{4}{ }^{+}-\mathrm{N}$, and $\mathrm{SOC}$ were the dominant factors controlling $\mathrm{CH}_{4}$ and $\mathrm{CO}_{2}$ fluxes from seven types of vegetation, and the $\mathrm{CH}_{4}$ and $\mathrm{CO}_{2}$ fluxes were influenced by different key environmental factors in the different forest types (Table 6).

In $\mathrm{OMF}, \mathrm{CH}_{4}$ fluxes had significant negative correlations with $\mathrm{pH}, \mathrm{NH}_{4}{ }^{+}-\mathrm{N}$, and $\mathrm{SOC}(p<0.05)$. In $\mathrm{KPP}, \mathrm{CH}_{4}$ fluxes had significant positive correlations with $\mathrm{SVWC}, \mathrm{NO}_{3}-\mathrm{N}$, and $\mathrm{NH}_{4}{ }^{+}-\mathrm{N}$, and negative correlations with air temperature $(p<0.01)$. In five secondary forests, $\mathrm{CH}_{4}$ fluxes had significant positive correlations with air temperature and negative correlations with soil temperature in HWF 
$(p<0.05)$ and MDF $(p<0.1)$. In BPF, $\mathrm{CH}_{4}$ fluxes had significant negative correlations with soil temperature and SOC, and positive correlations with SVWC and $\mathrm{NO}_{3}{ }^{-}-\mathrm{N}(p<0.001)$. In PDF and $\mathrm{MOF}, \mathrm{CH}_{4}$ fluxes had significant negative correlations with air temperature $(p<0.05)$ and $\mathrm{pH}(p<0.1)$, respectively (Table 6).

$\mathrm{CO}_{2}$ fluxes, as measured from KPP, OMF, and secondary forests, were significantly positively correlated with soil temperature $(p<0.001)$ (Table 6). In addition, $\mathrm{CO}_{2}$ fluxes from OMF also had significant positive correlations with SVWC and $\mathrm{NO}_{3}{ }^{-} \mathrm{N}(p<0.001)$. In $\mathrm{KPP}, \mathrm{CO}_{2}$ fluxes also had significant negative correlations with SVWC and $\mathrm{NO}_{3}{ }^{-}-\mathrm{N}$, and a positive correlation with $\mathrm{pH}$ $(p<0.001)$. In PDF, MDF, and MOF, $\mathrm{CO}_{2}$ fluxes also had significant correlations with air temperature (negative correlations in MDF and MOF), SVWC (positive correlations in PDF and MDF), pH (negative correlations in $\mathrm{PDF}$ ), $\mathrm{NO}_{3}{ }^{-}-\mathrm{N}$ (negative correlations in $\mathrm{MOF}$ ), and $\mathrm{SOC}$ (negative correlations in PDF, MDF, and MOF) (Table 6).

Table 6. The driving factors of $\mathrm{CH}_{4}$ and $\mathrm{CO}_{2}$ fluxes in seven types of vegetation at the Maoershan Ecosystem Research Station in Northeast China.

\begin{tabular}{|c|c|c|c|c|c|c|c|c|c|c|}
\hline Plot & AT & ST & SVWC & $\mathrm{pH}$ & $\mathrm{NO}_{3}{ }^{-}-\mathrm{N}$ & $\mathrm{NH}_{4}{ }^{+}-\mathrm{N}$ & SOC & Intercept & $\mathbf{R}^{2}$ & $p$ \\
\hline OMF & & & & $-0.056^{+}$ & & $-0.008^{*}$ & $-0.005^{* *}$ & $0.587^{*}$ & 0.663 & $<0.05$ \\
\hline KPP & $-0.002 *$ & & $0.002^{+}$ & & $0.004^{*}$ & $0.001^{+}$ & & $-0.129 * *$ & 0.842 & $<0.01$ \\
\hline HWF & $0.003 *$ & $-0.007^{*}$ & & & & & & $-0.045^{*}$ & 0.612 & $<0.05$ \\
\hline $\mathrm{BPF}$ & & $-0.004^{* *}$ & $0.002 *$ & & $0.198^{* * *}$ & & $-0.003^{+}$ & -0.117 * & 0.927 & $<0.001$ \\
\hline PDF & $-0.003^{* *}$ & & & & & & & $-0.047^{* * *}$ & 0.626 & $<0.01$ \\
\hline MDF & $0.004 *$ & $-0.007 *$ & & & & & & $-0.057^{* *}$ & 0.441 & $<0.1$ \\
\hline MOF & & & & $-0.160^{+}$ & & & & $0.836^{+}$ & 0.330 & $<0.1$ \\
\hline \multicolumn{11}{|c|}{ Models for soil $\mathrm{CO}_{2}$} \\
\hline OMF & & $12.920^{* * *}$ & $15.382 *$ & & & $14.930^{+}$ & & $-512.687 *$ & 0.891 & $<0.001$ \\
\hline KPP & & $21.477^{* * *}$ & $-6.017 *$ & $122.783^{+}$ & & $-2.275^{+}$ & & -476.729 & 0.973 & $<0.001$ \\
\hline HWF & & $16.692^{* * *}$ & & & & & & $114.102^{* * *}$ & 0.833 & $<0.001$ \\
\hline BPF & & $23.067^{* * *}$ & & & & & & $57.177^{*}$ & 0.895 & $<0.001$ \\
\hline PDF & & $25.094^{* * *}$ & $5.426^{+}$ & $-485.257^{+}$ & & & $-5.748^{+}$ & $2928.966^{*}$ & 0.944 & $<0.001$ \\
\hline MDF & $-8.155^{+}$ & $33.999 * * *$ & $11.265^{+}$ & & & & $-10.888 *$ & $454.856 *$ & 0.936 & $<0.001$ \\
\hline MOF & $-19.018 *$ & $49.746^{* * *}$ & & & $-112.542 *$ & & $-5.259+$ & $388.194^{* *}$ & 0.943 & $<0.001$ \\
\hline
\end{tabular}

\subsection{Net Primary Productivity and Annual Net C Sequestration}

Among seven investigative forest ecological systems, the annual net $C$ sequestration in vegetation (tree + shrub + herb) was significantly greater $(45.6 \%$ and $20.2 \%-83.6 \%)$ in KPP $\left(6.26 \mathrm{t} \mathrm{ha}^{-1} \mathrm{y}^{-1}\right)$ than in OMF (4.30 $\left.\mathrm{tha}^{-1} \mathrm{y}^{-1}\right)$ and secondary forests (3.41-5.21 $\mathrm{tha}^{-1} \mathrm{y}^{-1}$ ) (Table 7). From $82 \%$ to $97 \%$ of total vegetation $C$ sequestration was stored in trees, which was significantly different among the seven forest types $(p<0.05)$. Annual net $C$ sequestration (ANCS) was $1.1-1.5 \times$ greater $(p<0.05)$ in HWF $\left(5.21 \mathrm{t} \mathrm{ha}^{-1} \mathrm{y}^{-1}\right)$ than in either MDF $\left(4.76 \mathrm{tha}^{-1} \mathrm{y}^{-1}\right)$, MOF $\left(3.85 \mathrm{tha}^{-1} \mathrm{y}^{-1}\right)$, BPF $\left(4.38 \mathrm{tha}^{-1} \mathrm{y}^{-1}\right)$, or $\operatorname{PDF}\left(3.41 \mathrm{tha}^{-1} \mathrm{y}^{-1}\right)$, among the five secondary forests (Table 7).

KPP had the largest NPP $\left(11.84 \mathrm{t} \mathrm{ha}^{-1} \mathrm{y}^{-1}\right)$; it was $1.2-1.5 \times$ and $1.3 \times$ higher than that of five secondary forests and OMF for NPP, respectively (Table 7).

Table 7. Net primary productivity and net $C$ sequestration of seven types of vegetation at the Maoershan Ecosystem Research Station in Northeast China.

\begin{tabular}{|c|c|c|c|c|c|c|c|c|}
\hline \multirow{2}{*}{$\mathbf{u}$} & \multirow{2}{*}{ Layer } & \multicolumn{6}{|c|}{ Vegetation Types } & \multirow[b]{2}{*}{ MOF } \\
\hline & & OMF & KPP & HWF & BPF & PDF & MDF & \\
\hline \multirow{2}{*}{$\begin{array}{l}\text { Net Primary } \\
\text { Productivity } \\
\text { (NPP)/(t ha }{ }^{-1} \mathrm{a}^{-1} \text { ) }\end{array}$} & Arborous layer & $7.06 \pm 1.17 \mathrm{~B}$ & $11.44 \pm 1.40 \mathrm{~A}$ & $8.55 \pm 0.51 \mathrm{~B}$ & $7.98 \pm 0.56 \mathrm{~B}$ & $6.99 \pm 0.70 \mathrm{~B}$ & $8.81 \pm 0.72 \mathrm{~B}$ & $7.36 \pm 0.27 \mathrm{~B}$ \\
\hline & Shrubby layer & $0.08 \pm 0.02 \mathrm{AB}$ & $0.04 \pm 0.01 \mathrm{~B}$ & $0.10 \pm 0.01 \mathrm{~A}$ & $0.07 \pm 0.02 \mathrm{AB}$ & $0.08 \pm 0.01 \mathrm{AB}$ & $0.10 \pm 0.03 \mathrm{~A}$ & $0.06 \pm 0.01 \mathrm{AB}$ \\
\hline \multirow{4}{*}{$\begin{array}{l}\text { Annual NetC } \\
\text { Sequestration } \\
\text { (ANCS)/(t ha }{ }^{-1} \mathrm{a}^{-1} \text { ) }\end{array}$} & Arborous layer & $3.52 \pm 0.58 \mathrm{BC}$ & $6.08 \pm 0.75 \mathrm{~A}$ & $4.57 \pm 0.27 \mathrm{~B}$ & $3.68 \pm 0.25 B C$ & $3.06 \pm 0.31 \mathrm{C}$ & $4.42 \pm 0.36 \mathrm{BC}$ & $3.50 \pm 0.13 \mathrm{BC}$ \\
\hline & Shrubby layer & $0.03 \pm 0.01 \mathrm{AB}$ & $0.02 \pm 0.01 \mathrm{~B}$ & $0.05 \pm 0.01 \mathrm{~A}$ & $0.03 \pm 0.01 \mathrm{AB}$ & $0.03 \pm 0.01 \mathrm{AB}$ & $0.05 \pm 0.01 \mathrm{~A}$ & $0.03 \pm 0.01 \mathrm{AB}$ \\
\hline & Herbaceous layer & $0.75 \pm 0.43 \mathrm{~A}$ & $0.16 \pm 0.01 \mathrm{~A}$ & $0.59 \pm 0.15 \mathrm{~A}$ & $0.68 \pm 0.29 \mathrm{~A}$ & $0.32 \pm 0.04 \mathrm{~A}$ & $0.30 \pm 0.02 \mathrm{~A}$ & $0.32 \pm 0.04 \mathrm{~A}$ \\
\hline & Vegetation & $4.30 \pm 0.27 \mathrm{BCD}$ & $6.26 \pm 0.75 \mathrm{~A}$ & $5.21 \pm 0.25 \mathrm{AB}$ & $4.38 \pm 0.35 \mathrm{BCD}$ & $3.41 \pm 0.27 \mathrm{D}$ & $4.76 \pm 0.40 \mathrm{BC}$ & $3.85 \pm 0.16 \mathrm{CD}$ \\
\hline
\end{tabular}

Note: The different capital letters after numerical values indicate statistically significant differences within NPP or ANCS among different treatments. 


\subsection{Carbon Sources and Sinks}

The annual $\mathrm{C}$ emission (ACE; that is heterotrophic soil respiration) ranged from 3.15 to $5.89 \mathrm{tha}^{-1} \mathrm{y}^{-1}$ and differed significantly among the forest types $(p<0.05)$ (Table 8$)$. It decreased in the following order: secondary forests $\left(4.39-5.89 \mathrm{tha}^{-1} \mathrm{y}^{-1}\right)>$ Korean pine plantation $\left(3.72 \mathrm{t} \mathrm{ha}^{-1} \mathrm{y}^{-1}\right)>$ over-mature forest $\left(3.15 \mathrm{t} \mathrm{ha}^{-1} \mathrm{y}^{-1}\right)$ (Table 8).

Based on the difference between ANCS and ACE, in this study, OMF acted as a C sink ecosystem, accumulating $1.15 \mathrm{t} \mathrm{ha}^{-1} \mathrm{y}^{-1}$ (Table 8). The 51-year-old KPP acted as a strong $\mathrm{C}$ sink absorbing $2.54 \mathrm{tha}^{-1} \mathrm{y}^{-1}$ (Table 8), which was 1.2 times higher compared to OMF. Among the five secondary forests converted from over-mature forests 60-66 years ago, only HWF acted as a small $\mathrm{C}$ sink with $0.82 \mathrm{ha}^{-1} \mathrm{y}^{-1}$ (Table 8). However, the other four secondary forests acted as C sources emitting 1.12 (MDF), 1.27 (MOF), 0.89 (BPF), and $1.90 \mathrm{ha}^{-1} \mathrm{y}^{-1}$ (PDF), respectively (Table 8).

Table 8. The carbon source or sink from seven types of vegetation at the Maoershan Ecosystem Research Station in Northeast China.

\begin{tabular}{|c|c|c|c|c|c|c|c|}
\hline \multirow{2}{*}{ Item } & \multicolumn{7}{|c|}{ Vegetation Types } \\
\hline & OMF & KPP & HWF & BPF & PDF & MDF & MOF \\
\hline $\begin{array}{c}\text { Annual Net C } \\
\text { Sequestration } \\
\left(\text { ANCS)/(t ha }{ }^{-1} \mathrm{y}^{-1}\right)\end{array}$ & $4.30 \pm 0.27 \mathrm{BCD}$ & $6.26 \pm 0.75 \mathrm{~A}$ & $5.21 \pm 0.25 \mathrm{AB}$ & $4.38 \pm 0.35 \mathrm{BCD}$ & $3.41 \pm 0.27 \mathrm{D}$ & $4.76 \pm 0.40 \mathrm{BC}$ & $3.85 \pm 0.16 \mathrm{CD}$ \\
\hline $\begin{array}{l}\text { Annual C Emission } \\
(\mathrm{ACE}) /\left(\mathrm{t} \mathrm{ha}^{-1} \mathrm{y}^{-1}\right)\end{array}$ & $3.15 \pm 0.47 \mathrm{D}$ & $3.72 \pm 0.08 \mathrm{CD}$ & $4.39 \pm 0.12 \mathrm{BC}$ & $5.28 \pm 0.05 \mathrm{~A}$ & $5.32 \pm 0.37 \mathrm{~A}$ & $5.89 \pm 0.34 \mathrm{~A}$ & $5.12 \pm 0.21 \mathrm{AB}$ \\
\hline $\begin{array}{l}\text { Carbon Source/Sink } \\
(\mathrm{CSS}) /\left(\mathrm{t} \mathrm{ha}^{-1} \mathrm{y}^{-1}\right)\end{array}$ & $1.15 \pm 0.65 \mathrm{AB}$ & $2.54 \pm 0.80 \mathrm{~A}$ & $0.82 \pm 0.15 \mathrm{~B}$ & $-0.89 \pm 0.30 \mathrm{C}$ & $-1.90 \pm 0.64 \mathrm{C}$ & $-1.12 \pm 0.25 \mathrm{C}$ & $-1.27 \pm 0.37 \mathrm{C}$ \\
\hline
\end{tabular}

Note: The different capital letters after numerical values indicate statistically significant differences within ANCS, ACE, or ANCS among different treatments.

\section{Discussion}

\subsection{Carbon Fluxes}

\subsubsection{Methane Emission and Seasonal Dynamics}

Methane uptake by soils from seven forest types was observed in this study. This finding is consistent with the previous studies where the temperate forest soil acted as a net sink of atmospheric $\mathrm{CH}_{4}$ [60]. The annual average $\mathrm{CH}_{4}$ absorption increased in the following order: Korean pine plantation $<$ over-mature forest $<$ secondary forests, and small emissions to the atmosphere were observed in winter in the present study. The results indicated that the Korean pine plantation, over-mature forest, and secondary forest soils were all sinks for atmospheric $\mathrm{CH}_{4}$. The fundamental condition for producing methane in soils by the microbial decomposition of organic compounds was the strict anaerobic conditions [61]. When the reduction of sulphate, iron (III), nitrate, manganese (IV), and molecular oxygen was complete - that is to say, all of which maintained a higher potential- $\mathrm{CH}_{4}$ production was merely beginning [61]. Such low redox conditions usually required prolonged waterlogging, for instance, natural wetlands and in lake sediments, as well as flooded rice fields [61]. Soil moisture in the temperate forest of Northeast China did not accomplish the anaerobic conditions needed to affect the activities of $\mathrm{CH}_{4}$-consuming microbes during the monitoring period. Additionally, the shift in methanotrophic type is one of the factors that led to a change in soil $\mathrm{CH}_{4}$ oxidation [62], because the land-use changes greatly influence the methanotrophic community structure and activity [63]. Maurer et al. (2008) found that soil $\mathrm{CH}_{4}$ oxidation in methanotrophic community structure can be limited by toxic compounds from conifer species [64]. Thus, soil $\mathrm{CH}_{4}$ oxidation is impeded, which is the main reason for the lower $\mathrm{CH}_{4}$ absorption of the Korean pine plantation in this study area.

The soil $\mathrm{CH}_{4}$ fluxes among all the vegetation types have a clear seasonal pattern (Figure 1). The results showed that the permeability of atmospheric $\mathrm{O}_{2}$ into the soil had a significant impact on the balance between $\mathrm{CH}_{4}$ production (anaerobic environment) and consumption (aerobic environment), including the activities of methanogens and methanotrophs as well, which were affected by soil temperature, soil volumetric water content, and soil $\mathrm{pH}[65,66]$. It was found that the $\mathrm{CH}_{4}$ absorbing 
and releasing peak occurred in summer and winter, respectively (Figure 1). Additionally, the $\mathrm{CH}_{4}$ fluxes were negatively correlated with soil temperature $(p<0.05)$ (Table 5). These results indicate that high soil temperatures are necessary conditions for supporting the diffusion and exchange of $\mathrm{CH}_{4}$ produced by microbial activity between soil and atmosphere [67]. Optimal $\mathrm{CH}_{4}$ consumption occurred in samples that were incubated at temperatures between -5 and $10{ }^{\circ} \mathrm{C}$, and between 20 and $30{ }^{\circ} \mathrm{C}$, under which condition methanogen has high activity. Note soil temperature is the dominant factor of $\mathrm{CH}_{4}$ absorption in forest soil. However, $\mathrm{CH}_{4}$ consumption was greatly reduced at $40^{\circ} \mathrm{C}$ as the low and high temperature significantly reduce microbial activity [68]. Additionally, the soil temperature between 10 and $20{ }^{\circ} \mathrm{C}$ has no effect on $\mathrm{CH}_{4}$ consumption; this is because that other factors, such as soil moisture, become the most important controller of $\mathrm{CH}_{4}$ consumption [69]. According to Castro, Steudler [69], the minimum soil temperature is $-5^{\circ} \mathrm{C}$ in winter. However, in the present study, soil temperature below the depth of $5 \mathrm{~cm}$ was low (about $-16.4^{\circ} \mathrm{C}$ ) in winter. The low temperature in winter is considered to be one of the factors affecting $\mathrm{CH}_{4}$ release in forest soils.

\subsubsection{Carbon Dioxide Emission and Seasonal Dynamics}

The results of the present study indicate that the minimum $\mathrm{CO}_{2}$ emissions occurred within over-mature forest plots. $\mathrm{CO}_{2}$ emissions significantly increased in secondary forest soils relative to those in KPP and OMF in any season $(p<0.05)$ (Figure 2), which is in agreement with previous studies that proved that the average annual soil $\mathrm{CO}_{2}$ efflux of mixed coniferous and broad-leaved over-mature forest was significantly lower than that of middle-aged, broad-leaved secondary forest [70]. The litter found in secondary forests is known to decompose more readily than that of coniferous species found in plantations and coniferous and broadleaf mixed species of over-mature forest [71]. The more rapid turnover of litter in secondary forests was one of the reasons for greater $\mathrm{CO}_{2}$ emissions than the other sites. Seven forest types used for this study had historically similar soil status, hydrological condition, and original vegetation type. As such, differences in $\mathrm{CO}_{2}$ emissions among secondary forest, KPP, and OMF may reflect the impact of the change in vegetation structure and species composition, the accompanying difference in $\mathrm{C}$ allocation pattern [72], differences in the quantity and quality of litter [73], and changes in soil microclimate and structure [73,74]. After human disturbance and the operation of the over-mature forest, the average $\mathrm{CO}_{2}$ emissions during the whole year from KPP and secondary forests increased by various degrees. The most direct reason for the changes in soil-to-atmosphere $\mathrm{C}$ flux is the variation of land use.

A clear seasonal dynamic of $\mathrm{CO}_{2}$ flux was observed following seven vegetation types at the Maoershan Ecosystem Research Station in Northeast China (Figure 2). The lowest $\mathrm{CO}_{2}$ flux in this study occurred in winter and the peak flux was observed in the seasonal pattern in summer (Figure 2). This finding is in agreement with most of the previous studies [46,50,59]. There is a broad consensus that soil temperature is the key environmental factor to affect the seasonal $\mathrm{CO}_{2}$ emission dynamics [46,75]. The proper soil temperature could promote the increase of microbial activity and then easily enhance mineralization of unavailable decomposable organic substrates $[46,67]$. It was found that soil temperature had a positive correlation with $\mathrm{CO}_{2}$ emission (Table 5). Therefore, the peak $\mathrm{CO}_{2}$ emission observed in summer is affected by its higher temperature compared with winter [50].

\subsubsection{Emission Factors}

The $\mathrm{CH}_{4}$ uptake from secondary forests, KPP, and OMF had a negative correlation with air and soil temperature (Table 5). Sun [76] studied the characteristics of greenhouse gas emissions of soil from a typical forest in Beijing. The results indicated that $\mathrm{CH}_{4}$ emissions positively correlated with soil temperature. In contrast, Dong, Shen [77] found a negative relation between $\mathrm{CH}_{4}$ uptake and soil temperature. However, research by Fest, Hinko-Najera [78] showed that soil temperature only had a minor influence on soil $\mathrm{CH}_{4}$ uptake. Therefore, affirmative conclusions about the impacts of soil temperature on $\mathrm{CH}_{4}$ emissions (uptake) from forests have yet to be achieved. This may be related to different research methods, soil properties, and climatic conditions [79]. The relations between SVWC 
and $\mathrm{CH}_{4}$ fluxes are significantly positively and negatively correlated, having occurred at Korean pine plantation and secondary forest sites but not in over-mature forest sites. This may be because soil moistures of over-mature forest did not reach the water-holding field capacity during the measurement period [59]. Furthermore, the soil moisture contents in over-mature forest do not reach the marginal values needed to affect the activities of $\mathrm{CH}_{4}$ consuming microbes throughout the study period.

Stepwise multiple linear regression conducted in the present study showed that $\mathrm{CH}_{4}$ fluxes from seven different vegetation types were influenced by different environmental factors and had no regulation (Table 6). This was related to the combination of a multitude of environmental factors. In addition to environmental temperature and surface soil volumetric water content, high concentrations of $\mathrm{N}$ could increase $\mathrm{NH}_{4}{ }^{+}$-oxidizer bacteria that significantly inhibits methanotrophic activities in soils [80]. Some scholars believe that large $\mathrm{N}$ concentrations reduced the number of methanotrophic bacteria, which inhibited the capacity of $\mathrm{CH}_{4}$ oxidization [81]. However, studies have also shown that $\mathrm{N}$ provides sufficient nutrients for methane-oxidizing bacteria, thus promoting the process of methane oxidation. Methane-producing archaea also revealed high activity due to stimulation by sufficient nutrients and energy [82]. In addition, lower $\mathrm{pH}$ had adverse effects on methane-oxidizing bacteria, which could reduce the rate of methane oxidation [83]. On the other hand, higher soil moisture was not conducive to gas diffusion in soil and resulted in more $\mathrm{CH}_{4}$ reserved in the soil, which could provide sufficient substrate for methane-oxidizing bacteria and promote $\mathrm{CH}_{4}$ oxidation. However, higher humidity provided an anaerobic environment that could promote $\mathrm{CH}_{4}$ production $[50,84]$. The changes in SOC may directly limit the total mineralizable $\mathrm{C}$ used for sustaining microbial activity, including methanogenesis, thus impacting the net $\mathrm{CH}_{4}$ flux. In addition, the changes in $\mathrm{SOC}$ could affect other soil properties (such as water retention and soil fertility), and thus the soil $\mathrm{CH}_{4}$ oxidation and activities of methanotroph communities can also be indirectly affected $[50,66] . \mathrm{CH}_{4}$ production and consumption have different responses to different forest types due to the comprehensive influence of the above factors. There is currently little related mechanism research, especially in the function and activity of related microorganisms, which still need to be researched further.

Soil $\mathrm{CO}_{2}$ emissions from secondary forests, Korean pine plantation, and over-mature forest were positively correlated with soil temperature (Tables 5 and 6), which is not aligned with the conclusion that soil moisture is the most important factor for affecting the soil respiration and soil microbial activity [84], but is in accordance with the existing conclusion that soil temperature and soil volumetric water content are the most important factors for $\mathrm{CO}_{2}$ emissions [44]. The reason is that the increase of the soil temperature facilitates soil microbial activity and the decomposition of soil organic matter [85]. This leads to greater $\mathrm{CO}_{2}$ emissions as the soil temperature increases. One study indicated that soil microbial activity and the respiratory enzymes activity of plant roots increased as the temperature increased within the scope of $0-35{ }^{\circ} \mathrm{C}$ [86]. The condition of soil temperature is between -15.75 and $27.35{ }^{\circ} \mathrm{C}$ in the present study, and as such, the temperature of the growing season is suitable for microbial growth and $\mathrm{CO}_{2}$ emissions. Thus, there are clearly seasonal dynamics occurring in the $\mathrm{CO}_{2}$ fluxes in Northeast China. In addition, the present study exhibited the lower soil respiration from OMF with higher temperature and volume water content (Table 3). The content of soil moisture affects the production and emission of $\mathrm{CO}_{2}$ by influencing soil ventilation conditions, soil oxidation-reduction status, and the spread of the channel from soil to atmosphere [87]. Superfluous soil moisture causes the oxygen supply for microbial metabolism to reduce, resulting in a decrease in the soil respiration [79]. However, soil temperature could promote soil respiration [44]. The effect of soil moisture and temperature on $\mathrm{CO}_{2}$ emission frequently reveals strong interactions. The impacts of soil temperature on $\mathrm{CO}_{2}$ fluxes are covered by soil moisture effect in OMF. Furthermore, the composition of tree species and litters (conifer-broadleaf forest) that were difficult to decompose compared with broad-leaved forests were also the reason for high respiration from OMF [71].

In addition to environmental temperature and SVWC, the data presented in Table 6 shows that $\mathrm{CO}_{2}$ emissions were also controlled by soil $\mathrm{pH}$, soil nitrogen, and SOC. The soil $\mathrm{pH}$ in this study ranged from 4.1 to 7.9 , and previous studies have shown that it significantly affected soil microbial biomass 
and activity $[88,89]$. For soil nitrogen, on the one hand, the differences in soil nitrogen availability may facilitate $\mathrm{CO}_{2}$ emissions by stimulating the growth of microorganisms. On the other hand, soil nitrogen can reduce heterotrophic respiration by inhibiting decomposition of organic matter $[90,91]$. Additionally, negative correlations were observed in the present study between soil respiration rate and SOC in PDF, MDF, and MOF. This may be because SOC in the studied region was unable to provide adequate nutrition for soil organisms, leading to reduced biological activities and respiration rate.

\subsection{Net Primary Productivity and Net Carbon Sequestration}

The net primary productivity in the seven types of vegetation at the Maoershan Ecosystem Research Station (6.90-11.44 $\mathrm{t} \mathrm{ha}^{-1} \mathrm{y}^{-1}$ ) (Table 7) was higher than that reported for temperate forests in Northeast China (4.82-6.03 tha $\left.\mathrm{t}^{-1} \mathrm{y}^{-1}\right)$ [92]. This is because their study sites are located in the cool temperate zone with lower productivity than the forest site of the proposed experiment [92]; however, it may also be due to differences in water availability and nutrients [93]. The results of the current study showed that the pine plantation had a higher NPP than over-mature forest and secondary forest types because it was in a period of rapid growth and had higher concentrations of $\mathrm{NO}_{3}{ }^{-}-\mathrm{N}$ and $\mathrm{NH}_{4}{ }^{+}-\mathrm{N}$ with fertilization before 1965 (Table 3), that could significantly promote increased tree growth. Pine plantation with sufficient stand densities in the present study had a higher NPP than the other six forest types through the development of a multilayer canopy structure (Table 1) [94]. In addition, BPF had higher stand densities than the other forest types (Table 1), and the NPP in BPF was lower than that of pine plantation (Table 7). As the secondary forest and pine plantation have consistent stand age and environmental conditions, the growing ability of KPP is higher than other tree species. HWF was located at the foot of a mountain with a higher $\mathrm{C}$ collection compared with other forests (Table 3 ). Higher SOC caused it to have a higher NPP than the other secondary forest types.

The annual net $C$ sequestration varied between 0.34 and $0.63 \mathrm{~kg} \mathrm{C} \mathrm{m}^{-2} \mathrm{y}^{-1}$ among seven investigative ecosystems, thus the ability of annual $\mathrm{C}$ sequestration of terrestrial vegetation in China $\left(0.49 \mathrm{~kg} \mathrm{C} \mathrm{m}^{-2} \mathrm{y}^{-1}\right)$ [95] and global annual C sequestration $\left(0.41 \mathrm{~kg} \mathrm{C} \mathrm{m}^{-2} \mathrm{y}^{-1}\right)$ [96] were used for comparison. It was found that KPP had the largest biomass $C$ sequestration rate, higher than the Chinese and global mean level by $28.6 \%$ and $53.7 \%$, respectively. While the rate for OMF $(0.43 \mathrm{~kg}$ $\mathrm{C} \mathrm{m}^{-2} \mathrm{y}^{-1}$ ) was similar to the Chinese mean level, and four secondary forests (except for HWF) for annual $\mathrm{C}$ sequestration were lower than the Chinese mean level by $2.9 \%-30.0 \%$. This result shows that secondary forests have an intermediate-level capacity of $C$ sequestration; however, KPP has the strongest biomass $C$ sequestration capacity. The divergent sequestration rates may be due to different forest practices, different species, and densities of growing trees, or differences in soil properties.

\subsection{Carbon Balance}

The annual soil heterotrophic respiration $\left(\mathrm{R}_{\mathrm{H}}\right)$ reported in the present study agrees with previous research that the forest ecosystem respiration reveals a downward trend from younger to older forests [97]. Additionally, the finding showed that the secondary forests and KPP had a higher annual $\mathrm{R}_{\mathrm{H}}$ than in the mixed forest [92]. As an important process of releasing $C$ from soils to the atmosphere, every forest type has the different biophysical environments associated with them, which leads to their different $R_{H}$ [98]. Moreover, the difference of size and source of the $R_{H}$ among different forest types was influenced by disturbance history through converting live vegetation into dead materials [99].

The function of seven forests as $C$ sources and sinks was not identical at the Maoershan Ecosystem Research Station in Northeast China. The five secondary forests emerged as weak $C$ sinks or net $C$ sources; this is consistent with the previous conclusion that the downy birch stand (78 years of age) acted as a $\mathrm{C}$ source emitting $0.95 \mathrm{tC} \mathrm{ha}^{-1} \mathrm{a}^{-1}$ [10]. In contrast, OMF and KPP acted as stronger net $\mathrm{C}$ sinks in this study that was in the range reported for temperate forests [97]. This is owing to the intensive annual biomass production of the trees and management of such forests, which is essential in terms of effective $C$ accumulation. The annual biomass production of an ecosystem increases, i.e., the $C$ input exceeds $C$ emission through soil $R_{H}[10]$; however, as a net $C$ source, secondary forests may suffer 
biological aging as well as a slow increase in DBH and volume, which leads to a significant decrease in the individual competition. Therefore, the secondary forest growth shows some stability [100]. The carbon sequestration of secondary forests is lower than that of KPP, but its soil C emissions are higher than that of KPP, thereby making secondary forests net $C$ sources. KPP studied in this research was in a middle-aged stage and presented a stronger $C$ sequestration ability at the intermediate stage of succession, and the $\mathrm{C}$ emissions of soil respiration were at a comparatively low level, thereby making it a stronger net $C$ sinks. The annual net $C$ sequestration and annual $C$ emission of OMF were at a mid level $(p>0.05)$ and low level $(p<0.05)$ compared with the other forest ecosystems, respectively (Table 8$)$. Therefore, the results of this study demonstrate that OMF is a net $C$ sink. These results indicate that old-growth forests can still act as large $C$ sinks. The regenerated forest types of approximately 60 years of age were weak $C$ sinks or net $C$ sources (secondary forest) and stronger net $C$ sinks (Korean pine plantation) at the Maoershan Ecosystem Research Station in Northeast China.

\section{Conclusions}

In general, the absorption value of $\mathrm{CH}_{4}$ in secondary forest soils was significantly higher than that of OMF and KPP soils because the land-use changes led to shifts in methanotrophic type. However, the toxic compounds produced by conifer species can limit soil $\mathrm{CH}_{4}$ oxidation. Additionally, $\mathrm{CO}_{2}$ emissions from OMF and KPP soils were lower than that of soils of the secondary forests. This may be influenced by the change in tree species, the ensuing difference in the pattern of $\mathrm{C}$ allocation, differences in the quantity and quality of litter, and changes in soil structure and microclimate. $\mathrm{The} \mathrm{CH}_{4}$ and $\mathrm{CO}_{2}$ fluxes were mainly controlled by air and soil temperature, soil volumetric moisture content, soil $\mathrm{pH}$, ammonium nitrogen, nitrate nitrogen, and the soil organic carbon.

According to the difference between annual net $C$ sequestration and $C$ released from the soil in Northeast China, the over-mature forests remain C sinks despite being more than 150 years old, and Korean pine plantations (51 years old) are determined to be $C$ sinks. The net primary productivity of $\mathrm{KPP}$ was 1.2 to $1.5 \times$ higher than that of other forest types because the higher concentrations of $\mathrm{NO}_{3}{ }^{-}-\mathrm{N}$ and $\mathrm{NH}_{4}{ }^{+}-\mathrm{N}$ could promote the rapid growth of KPP with sufficient stand densities. Therefore, the role of over-mature forests and Korean pine plantation in regulating regional $\mathrm{C}$ balance should be explored in more detail, especially the selection of tree species in artificial afforestation. However, 60-year-old secondary forests that were regenerated naturally after clearcutting in Northeast China are small $\mathrm{C}$ sinks or main sources. This is caused by relatively high soil respiration and slow forest growth compared with OMF and KPP. The influence of secondary forest on regional $C$ balance needs to be researched continuously and over a long period. It is especially important to study the secondary forests with different age gradients.

The authors of this paper, to strengthen $C$ sink and $C$ sequestration capacity of forests, recommends considering the following measures: (1) after forest regeneration, new stands (because of their high increments) start to accumulate more annual $C$ than old-growth stands. Therefore, reasonable and sustainable forest harvesting and regeneration could be conducted. The young regenerated forest with high increments should be managed effectively. (2) Trees and timber after harvesting should be processed and utilized as much as possible; their comprehensive utilization rate should also be improved. As woody materials obtained from harvesting can be used for making building, furniture, and others, an important amount of carbon would be sequestered for long years apart from forests. This can be considered as a positive output of forest regeneration.

Further studies are required for the comparison of the $C$ sources and sinks between over-mature forest, natural secondary forests, plantations, and croplands to forecast which vegetation type is the most similar to the over-mature forest in the aspects of ecosystem $C$ cycles.

Author Contributions: C.M. and B.W. conceived the general idea of the paper; All authors analyzed and discussed the results; B.W. and C.M. wrote and revised the paper; C.M. reviewed the edited manuscript. 
Funding: The authors wish to acknowledge financial assistance supported by the National Key Research and Development Program of China (2017YFC0504102), and the National Natural Science Foundation of China (41430639).

Acknowledgments: We would like to thank Xiuxiu Wang for her help with the laboratory analyses. We also would like to thank the reviewers and editors for their time and effort.

Conflicts of Interest: The authors are well informed about the study's objectives, provided consent, and have declared no competing interest.

\section{References}

1. Schimel, D.S.; House, J.I.; Hibbard, K.A.; Bousquet, P.; Ciais, P.; Peylin, P.; Braswell, B.H.; Apps, M.J.; Baker, D.; Bondeau, A. Recent patterns and mechanisms of carbon recent patterns and mechanisms of carbon exchange by terrestrial ecosystems. Nature 2001, 414, 169-172. [CrossRef] [PubMed]

2. Shiogama, H.; Ogura, T. Climate science: Clouds of uncertainty. Nature 2014, 515, 34. [CrossRef] [PubMed]

3. Tian, H.; Melillo, J.M.; Kicklighter, D.W.; McGuire, A.D.; Helfrich, J. The sensitivity of terrestrial carbon storage to historical climate variability and atmospheric $\mathrm{CO}_{2}$ in the United States. Tellus B Chem. Phys. Meteorol. 1999, 51, 414-452. [CrossRef]

4. Gundersen, P.; Christiansen, J.R.; Alberti, G.; Brüggemann, N.; Castaldi, S.; Gasche, R.; Kitzler, B.; Klemedtsson, L.; Lobo-do-Vale, R.; Moldan, F.; et al. The response of methane and nitrous oxide fluxes to forest change in Europe. Biogeosciences 2012, 9, 6129-6168. [CrossRef]

5. Dixon, R.K.; Solomon, A.M.; Brown, S.; Houghton, R.A.; Trexier, M.C.; Wiśniewski, J. Carbon Pools and Flux of Global Forest Ecosystems. Science 1994, 263, 185-190. [CrossRef] [PubMed]

6. Zeng, Z.Q.; Wang, S.L.; Zhang, C.M.; Gong, C.; Hu, Q. Carbon storage in evergreen broad-leaf forests in mid-subtropical re-gion of China at four succession stages. J. For. Res. 2013, 24, 677-682. [CrossRef]

7. Callewaert, P.; Lenders, S.; Gryze, S.D.; Morris, S.J.; Gregorich, E.G.; Paul, E.A.; Paustian, K. Measuring and understanding carbon storage in afforested soils by physical fractionation. Soil Sci. Soc. Am. J. 2007, 66, 1981-1987.

8. Vogt, K. Carbon budgets of temperate forest ecosystems. Tree Physiol. 1991, 9, 69-86. [CrossRef]

9. Luyssaert, S.; Inglima, I.; Jung, M.; Richardson, A.D.; Reichsteins, M.; Papale, D.; Piao, S.1.; Schulzes, E.D.; Wingate, L.; Matteucci, G.; et al. $\mathrm{CO}_{2}$ balance of boreal, temperate, and tropical forests derived from a global database. Glob. Chang. Biol. 2007, 13, 2509-2537. [CrossRef]

10. Veiko, U.; Mai, K.; Jürgen, A.; Mats, V.; Hardo, B.; Gunnar, M.; Kalle, K. Ecosystems carbon budgets of differently aged downy birch stands growing on well-drained peatlands. For. Ecol. Manag. 2017, 399, 82-93.

11. Valentini, R.; Matteucci, G.; Dolman, A.J.; Schulze, E.-D.; Rebmann, C.; Moors, E.J.; Granier, A.; Gross, P.; Jensen, N.O.; Pilegaard, K.; et al. Respiration as the main determinant of carbon balance in European forests. Nature 2000, 404, 861-865. [CrossRef]

12. Liski, J.; Nissinen, A.; Erhard, M.; Taskinen, O. Climatic effects on litter decomposition from Arctic tundra to tropical rainforest. Glob. Chang. Biol. 2010, 9, 575-584. [CrossRef]

13. Kaipainen, T.; Liski, J.; Pussinen, A.; Karjalainen, T. Managing carbon sinks by changing rotation length in European forests. Environ. Sci. Policy 2004, 7, 205-219. [CrossRef]

14. Pacala, S.W.; Hurtt, G.C.; Baker, D.; Peylin, P.; Houghton, R.A.; Birdsey, R.A.; Heath, L.; Sundquist, E.T.; Stallard, R.; Ciais, P.; et al. Consistent Land- and Atmosphere-Based U.S. Carbon Sink Estimates. Science 2001, 292, 2316-2320. [CrossRef]

15. Law, B.E.; Thornton, P.E.; Irvine, J.; Anthoni, P.M.; Tuyl, S.V. Carbon storage and fluxes in ponderosa pine forests at different developmental stages. Glob. Chang. Biol. 2010, 7, 755-777. [CrossRef]

16. Schulze, E.-D.; Lloyd, J.; Kelliher, F.M.; Wirth, C.; Rebmann, C.; Lühker, B.; Mund, M.; Knohl, A.; Milyukova, I.M.; Schulze, W.; et al. Productivity of forests in the Eurosiberian boreal region and their potential to act as a carbon sink-A synthesis. Glob. Chang. Boil. 1999, 5, 703-722. [CrossRef]

17. Machimura, T.; Kobayashi, Y.; Lwahana, G.; Hirano, T.; Lopez, L.; Fukuda, M.; Fedorov, A.N. Change of Carbon Dioxide Budget during Three Years after Deforestation in Eastern Siberian Larch Forest. J. Agric. Meteorol. 2005, 60, 653-656. [CrossRef] 
18. Zaehle, S.; Bondeau, A.; Carter, T.R.; Cramer, W.; Erhard, M.; Prentice, I.C.; Reginster, I.; Rounsevell, M.D.A.; Sitch, S.; Smith, B.; et al. Projected Changes in Terrestrial Carbon Storage in Europe under Climate and Land-use Change, 1990-2100. Ecosystems 2007, 10, 380-401. [CrossRef]

19. Singh, J.S.; Singh, D.P. Reforestation: A potential approach to mitigate excess atmospheric $\mathrm{CH}_{4}$ build-up. Ecol. Manag. Restor. 2012, 13, 245-248. [CrossRef]

20. Poeplau, C.; Don, A. Sensitivity of soil organic carbon stocks and fractions to different land-use changes across Europe. Geoderma 2013, 192, 189-201. [CrossRef]

21. Geider, R.J.; Delucia, E.H.; Falkowski, P.G.; Finzi, A.C.; Grime, J.P.; Grace, J.; Kana, T.M.; Roche, J.L.; Long, S.P.; Osborne, B.A.; et al. Primary productivity of planet earth: Biological determinants and physical constraints in terrestrial and aquatic habitats. Glob. Chang. Biol. 2002, 7, 849-882. [CrossRef]

22. Battle, M.; Bender, M.L.; Tans, P.P.; White, J.W.C.; Ellis, J.T.; Conway, T.; Francey, R.J. Global carbon sinks and their variability inferred from atmospheric $\mathrm{O} 2$ and $\delta 13$ C. Science 2000, 287, 2467-2470. [CrossRef]

23. Schimel, D. Contribution of Increasing CO2 and Climate to Carbon Storage by Ecosystems in the United States. Science 2000, 287, 2004-2006. [CrossRef]

24. Clark, K.L.; Gholz, H.L.; Castro, M.S. Carbon Dynamics Along a Chronosequence of Slash Pine Plantations in North Florida. Ecol. Appl. 2004, 14, 1154-1171. [CrossRef]

25. Kowalski, S.; Sartore, M.; Burlett, R.; Berbigier, P.; Loustau, D. The annual carbon budget of a French pine forest (Pinus pinaster) following harvest. Glob. Chang. Biol. 2010, 9, 1051-1065. [CrossRef]

26. chulze, E.D.; Wirth, C.; Heimann, M. Managing forests after Kyoto. Science 2000, 289, 2058-2059. [CrossRef]

27. Cohen, W.B.; Harmon, M.E.; Wallin, D.O.; Fiorella, M. Two Decades of Carbon Flux from Forests of the Pacific Northwest. Bioscience 1996, 46, 836-844. [CrossRef]

28. Laporte, M.; Duchesne, L.; Morrison, I. Effect of clearcutting, selection cutting, shelterwood cutting and microsites on soil surface $\mathrm{CO}_{2}$ efflux in a tolerant hardwood ecosystem of northern Ontario. Ecol. Manag. 2003, 174, 565-575. [CrossRef]

29. Coutinho, R.P.; Urquiaga, S.; Boddey, R.M.; Alves, B.J.R.; Torres, A.Q.A.; Jantalia, C.P. Estoque de carbono e nitrogênio e emissão de N2O em diferentes usos do solo na Mata Atlântica. Pesqui. Agropecuária Bras. 2010, 45, 195-203. [CrossRef]

30. Shi, B.; Gao, W.; Jin, G. Effects on rhizospheric and heterotrophic respiration of conversion from primary forest to secondary forest and plantations in northeast China. Eur. J. Soil Boil. 2015, 66, 11-18. [CrossRef]

31. Sheng, H.; Yang, Y.; Yang, Z.; Chen, G.; Xie, J.; Guo, J.; Zou, S. The dynamic response of soil respiration to land-use changes in subtropical China. Glob. Chang. Boil. 2010, 16, 1107-1121. [CrossRef]

32. Shi, Z.; Li, Y.; Wang, S.; Wang, G.; Ruan, H.; He, R.; Tang, Y.; Zhang, Z. Accelerated soil CO2 efflux after conversion from secondary oak forest to pine plantation in southeastern China. Ecol. Res. 2009, 24, 1257-1265. [CrossRef]

33. Prescott, C. Effects of clearcutting and alternative silvicultural systems on rates of decomposition and nitrogen mineralization in a coastal montane coniferous forest. Ecol. Manag. 1997, 95, 253-260. [CrossRef]

34. Ewel, K.C.; Cropper, W.P., Jr.; Gholz, H.L. Soil CO2 evolution in Florida slash pine plantations. I. Changes through time. Can. J. Res. 1987, 17, 325-329. [CrossRef]

35. Kolari, P.; Pumpanen, J.; Rannik, Ü.; Ilvesniemi, H.; Hari, P.; Berninger, F. Carbon balance of different aged Scots pine forests in Southern Finland. Glob. Chang. Biol. 2010, 10, 1106-1119. [CrossRef]

36. Litton, C.M.; Ryan, M.G.; Knight, D.H.; Stahl, P.D. Soil-Surface carbon dioxide efflux and microbial biomass in relation to tree density 13 years after a stand replacing fire in a lodgepole pine ecosystem. Glob. Chang. Biol. 2010, 9, 680-696. [CrossRef]

37. Misson, L.; Tang, J.; Xu, M.; McKay, M.; Goldstein, A. Influences of recovery from clear-cut, climate variability, and thinning on the carbon balance of a young ponderosa pine plantation. Agric. Meteorol. 2005, 130, $207-222$. [CrossRef]

38. Veldkamp, E.; Purbopuspito, J.; Corre, M.D.; Brumme, R.; Murdiyarso, D. Land use change effects on trace gas fluxes in the forest margins of Central Sulawesi, Indonesia. J. Geophys. Res. Space Phys. 2008, 113. [CrossRef]

39. Keller, M.; Reiners, W.A. Soil-atmosphere exchange in nitrous oxide, nitric oxide, and methane under secondary succession of pasture to forest in the Atlantic lowlands of Costa Rica. Glob. Biogeochem. Cycles 1994, 8, 399-409. [CrossRef] 
40. Hiltbrunner, D.; Zimmermann, S.; Karbin, S.; Hagedorn, F.; Niklaus, P.A. Increasing soil methane sink along a 120-year afforestation chronosequence is driven by soil moisture. Glob. Chang. Boil. 2012, 18, 3664-3671. [CrossRef]

41. Priemé, A.; Christensen, S. Seasonal and spatial variation of methane oxidation in a Danish spruce forest. Soil Boil. Biochem. 1997, 29, 1165-1172. [CrossRef]

42. Benanti, G.; Saunders, M.; Tobin, B.; Osborne, B. Contrasting impacts of afforestation on nitrous oxide and methane emissions. Agric. Meteorol. 2014, 198, 82-93. [CrossRef]

43. Houghton, R.A. The annual net flux of carbon to the atmosphere from changes in land use 1850-1990. Tellus B Chem. Phys. Meteorol. 1999, 51, 298-313. [CrossRef]

44. Wang, C.K.; Yang, J.Y.; Zhang, Q.Z. Soil respiration in six temperate forests in China. Glob. Chang. Biol. 2006, 12, 2103-2114. [CrossRef]

45. Zhang, H.D.; You, W.Z.; Xing, Z.K.; Wei, W.J.; Zhao, G.; Yan, T.W. Soil respiration of natural secondary forest and larch plantation in Montane region of eastern Liaoning province. J. Soil Water Conserv. 2011, 25, $198-201$.

46. Li, Y.; Dong, S.; Liu, S.; Zhou, H.; Gao, Q.; Cao, G.; Wang, X.; Su, X.; Zhang, Y.; Tang, L.; et al. Seasonal changes of $\mathrm{CO} 2, \mathrm{CH} 4$ and $\mathrm{N} 2 \mathrm{O}$ fluxes in different types of alpine grassland in the Qinghai-Tibetan Plateau of China. Soil Boil. Biochem. 2015, 80, 306-314. [CrossRef]

47. Wang, X.; Wang, C.; Guo, Q.; Wang, J. Improving the $\mathrm{CO}_{2}$ storage measurements with a single profile system in a tall-dense-canopy temperate forest. Agric. Meteorol. 2016, 228, 327-338. [CrossRef]

48. Wang, C.K. Biomass allometric equations for 10 co-occurring tree species in Chinese temperate forests. Ecol. Manag. 2006, 222, 9-16. [CrossRef]

49. Chen, D.K.; Zhou, X.F.; Zhao, H.X.; Wang, Y.H.; Jing, Y.Y. Study on the Structure, Function and Succession of the Four Types in Natural Secondary Forest; Northeast Forestry University Press: Harbin, China, 1982.

50. Dou, X.; Zhou, W.; Zhang, Q.; Cheng, X. Greenhouse gas $\left(\mathrm{CO}_{2}, \mathrm{CH}_{4}, \mathrm{~N}_{2} \mathrm{O}\right)$ emissions from soils following afforestation in central China. Atmos. Environ. 2015, 126, 98-106. [CrossRef]

51. Van Miegroet, H.; Nicholas, N.S.; Creed, I.F.; Barker, M. Variation in overstory nitrogen uptake in a small, high-elevation southern Appalachian spruce-fir watershed. Can. J. Res. 2002, 32, 1741-1752.

52. Yarie, J. The Role of Understory Vegetation in the Nutrient Cycle of Forested Ecosystems in the Mountain Hemlock Biogeoclimatic Zone. Ecology 1980, 61, 1498-1514. [CrossRef]

53. Van Miegroet, H.; Moore, P.; Tewksbury, C.; Nicholas, N. Carbon sources and sinks in high-elevation spruce-fir forests of the Southeastern US. Ecol. Manag. 2007, 238, 249-260. [CrossRef]

54. Bhatia, A.; Sasmal, S.; Jain, N.; Pathak, H.; Kumar, R.; Singh, A. Mitigating nitrous oxide emission from soil under conventional and no-tillage in wheat using nitrification inhibitors. Agric. Ecosyst. Environ. 2010, 136, 247-253. [CrossRef]

55. Jain, N.; Arora, P.; Tomer, R.; Mishra, S.V.; Bhatia, A.; Pathak, H.; Chakraborty, D.; Kumar, V.; Dubey, D.; Harit, R.; et al. Greenhouse gases emission from soils under major crops in Northwest India. Sci. Total Environ. 2016, 542, 551-561. [CrossRef]

56. Mu, C.C.; Cheng, W.; Sun, X.X.; Wu, Y.X. Seasonal Variation of Emission Fluxes of CO2, N2O and CH4 from Larix gemlinii Swamps Soils in Xiaoxing'An Mountains of China. Sci. Silvae Sin. 2010, 46, 7-15.

57. Carmo, J.B.D.; Neto, E.R.D.S.; Duarte-Neto, P.J.; Ometto, J.P.H.B.; Martinelli, L.A. Conversion of the coastal Atlantic forest to pasture: Consequences for the nitrogen cycle and soil greenhouse gas emissions. Agric. Ecosyst. Environ. 2012, 148, 37-43. [CrossRef]

58. Mu, C.C.; Zhang, B.W.; Han, L.D.; Yu, L.L.; Gu, H. Short-term effects of fire disturbance on greanhouse gases emission from Betula platyphylla-forested wetland in Xiaoxing'an Mountains, Northeast China. Chin. J. Appl. Ecol. 2011, 22, 857-865.

59. Tang, X.; Liu, S.; Zhou, G.; Zhang, D.; Zhou, C. Soil-atmospheric exchange of $\mathrm{CO}_{2}, \mathrm{CH}_{4}$, and $\mathrm{N}_{2} \mathrm{O}$ in three subtropical forest ecosystems in southern China. Glob. Chang. Biol. 2006, 12, 546-560. [CrossRef]

60. Geng, S.C.; Chen, Z.J.; Zhang, J.H.; Lou, X.; Wang, X.X.; Dai, G.H.; Han, S.J.; Yu, D.D. Soil methane fluxes of three forest types in Changbai Mountain of Northeast China. Chin. J. Ecol. 2013, 32, 1091-1096.

61. Smith, K.A.; Ball, T.; Conen, F.; Dobbie, K.E.; Massheder, J.; Rey, A. Exchange of greenhouse gases between soil and atmosphere: Interactions of soil physical factors and biological processes. Eur. J. Soil Sci. 2003, 54, 779-791. [CrossRef] 
62. Tate, K.; Ross, D.; Saggar, S.; Hedley, C.; Dando, J.; Singh, B.; Lambie, S. Methane uptake in soils from Pinus radiata plantations, a reverting shrubland and adjacent pastures: Effects of land-use change, and soil texture, water and mineral nitrogen. Soil Boil. Biochem. 2007, 39, 1437-1449. [CrossRef]

63. Kolb, S. The quest for atmospheric methane oxidizers in forest soils. Environ. Microbiol. Rep. 2009, 1, 336-346. [CrossRef]

64. Maurer, D.; Kolb, S.; Haumaier, L.; Borken, W. Inhibition of atmospheric methane oxidation by monoterpenes in Norway spruce and European beech soils. Soil Boil. Biochem. 2008, 40, 3014-3020. [CrossRef]

65. Konda, R.; Ohta, S.; Ishizuka, S.; Heriyanto, J.; Wicaksono, A. Seasonal changes in the spatial structures of $\mathrm{N}_{2} \mathrm{O}, \mathrm{CO}_{2}$, and $\mathrm{CH}_{4}$ fluxes from Acacia mangium plantation soils in Indonesia. Soil Boil. Biochem. 2010, 42, 1512-1522. [CrossRef]

66. Tate, K.R. Soil methane oxidation and land-use change-From process to mitigation. Soil Boil. Biochem. 2015, 80, 260-272. [CrossRef]

67. Wu, X.; Yao, Z.; Brüggemann, N.; Shen, Z.; Wolf, B.; Dannenmann, M.; Zheng, X.; Butterbach-Bahl, K.; Shen, Z. Effects of soil moisture and temperature on $\mathrm{CO}_{2}$ and $\mathrm{CH}_{4}$ soil-atmosphere exchange of various land use/cover types in a semi-arid grassland in Inner Mongolia, China. Soil Boil. Biochem. 2010, 42, 773-787. [CrossRef]

68. Nesbit, S.; Breitenbeck, G. A laboratory study of factors influencing methane uptake by soils. Agric. Ecosyst. Environ. 1992, 41, 39-54. [CrossRef]

69. Melillo, J.M.; Aber, J.D.; Castro, M.S.; Steudler, P.A.; Bowden, R.D. Factors controlling atmospheric methane consumption by temperate forest soils. Glob. Biogeochem. Cycles 1995, 9, 1-10.

70. Wang, X.; Jiang, Y.; Jia, B.; Wang, F.; Zhou, G. Comparison of soil respiration among three temperate forests in Changbai Mountains, China. Can. J. Res. 2010, 40, 788-795. [CrossRef]

71. Zhang, P.; Tian, X.; He, X.; Song, F.; Ren, L.; Jiang, P. Effect of litter quality on its decomposition in broadleaf and coniferous forest. Eur. J. Soil Boil. 2008, 44, 392-399. [CrossRef]

72. Imaji, A.; Seiwa, K. Carbon allocation to defense, storage, and growth in seedlings of two temperate broad-leaved tree species. Oecologia 2010, 162, 273-281. [CrossRef]

73. Vesterdal, L.; Elberling, B.; Christiansen, J.R.; Callesen, I.; Schmidt, I.K. Soil respiration and rates of soil carbon turnover differ among six common European tree species. Ecol. Manag. 2012, 264, 185-196. [CrossRef]

74. Christiansen, J.R.; Vesterdal, L.; Callesen, I.; Elberling, B.; Schmidt, I.K.; Gundersen, P. Role of six European tree species and land-use legacy for nitrogen and water budgets in forests. Glob. Chang. Biol. 2010, 16, 2224-2240. [CrossRef]

75. Liu, H.; Zhao, P.; Lu, P.; Wang, Y.-S.; Lin, Y.-B.; Rao, X.-Q. Greenhouse gas fluxes from soils of different land-use types in a hilly area of South China. Agric. Ecosyst. Environ. 2008, 124, 125-135. [CrossRef]

76. Sun, X. A Study on Forest Soil CO2, N2O and CH4 Emission Flux and Dynamics in Xishan Area, Beijing; Beijing Forestry University Press: Beijing, China, 1999.

77. Dong, Y.; Zhang, S.; Qi, Y.; Chen, Z.; Geng, Y. Fluxes of $\mathrm{CO}_{2}, \mathrm{~N}_{2} \mathrm{O}$ and $\mathrm{CH}_{4}$ from a typical temperate grassland in Inner Mongolia and its daily variation. Chin. Sci. Bull. 2000, 45, 1590-1594. [CrossRef]

78. Fest, B.J.; Hinko-Najera, N.; Wardlaw, T.; Griffith, D.W.T.; Livesley, S.J.; Arndt, S.K. Soil methane oxidation in both dry and wet temperate eucalypt forests shows a near-identical relationship with soil air-filled porosity. Biogeosciences 2017, 14, 467-479. [CrossRef]

79. Davidson, E.A.; Verchot, L.V.; Cattânio, J.H.; Ackerman, I.L.; Carvalho, J. Effects of soil water content on soil respiration in forests and cattle pastures of eastern Amazonia. Biogeochemistry 2000, 48, 53-69. [CrossRef]

80. Whalen, S.; Reeburgh, W. Effect of nitrogen fertilization on atmospheric methane oxidation in boreal forest soils. Chemosphere-Glob. Chang. Sci. 2000, 2, 151-155. [CrossRef]

81. Reay, D.S.; Nedwell, D.B. Methane oxidation in temperate soils: Effects of inorganic N. Soil Boil. Biochem. 2004, 36, 2059-2065. [CrossRef]

82. Visscher, A.D.; Cleemput, O.V. Induction of enhanced CH4 oxidation in soils: NH4+ inhibition patterns. Soil Biol. Biochem. 2003, 35, 907-913. [CrossRef]

83. Bradford, M.; Wookey, P.; Ineson, P.; Lappin-Scott, H.; Bradford, M. Controlling factors and effects of chronic nitrogen and sulphur deposition on methane oxidation in a temperate forest soil. Soil Boil. Biochem. 2001, 33, 93-102. [CrossRef]

84. Sun, X.; Mu, C.; Shi, L.; Cheng, W.; Liu, X.; Wu, Y.; Feng, D. Methane emission from forested swamps in Xiaoxing'an Mountains, Northeastern China. Chin. J. Plant Ecol. 2009, 33, 535-545. 
85. Amundson, R.; Niu, X.-F.; Wang, Y.; Niu, X. Seasonal and altitudinal variation in decomposition of soil organic matter inferred from radiocarbon measurements of soil $\mathrm{CO}_{2}$ flux. Glob. Biogeochem. Cycles 2000, 14, 199-211.

86. Andrews, J.A.; Matamala, R.; Westover, K.M.; Schlesinger, W.H. Temperature effects on the diversity of soil heterotrophs and the $\delta 13 \mathrm{C}$ of soil-respired $\mathrm{CO}_{2}$. Soil Boil. Biochem. 2000, 32, 699-706. [CrossRef]

87. Dong, Y.J.; Cai, M.; Zhou, J.B. Effects of moisture and carbonate additions on CO2 emission from calcareous soil during closed-jar incubation. J. Arid Land 2014, 6, 37-43. [CrossRef]

88. Oertel, C.; Matschullat, J.; Zurba, K.; Zimmermann, F.; Erasmi, S. Greenhouse gas emissions from soils-A review. Geochemistry 2016, 76, 327-352. [CrossRef]

89. Tian, Y.; Haibara, K.; Toda, H.; Ding, F.; Liu, Y.; Choi, D. Microbial biomass and activity along a natural $\mathrm{pH}$ gradient in forest soils in a karst region of the upper Yangtze River, China. J. Res. 2008, 13, 205-214. [CrossRef]

90. Wang, Q.; Wang, S.; He, T.; Liu, L.; Wu, J. Response of organic carbon mineralization and microbial community to leaf litter and nutrient additions in subtropical forest soils. Soil Boil. Biochem. 2014, 71, 13-20. [CrossRef]

91. Weintraub, M.N.; Schimel, J.P. Interactions between Carbon and Nitrogen Mineralization and Soil Organic Matter Chemistry in Arctic Tundra Soils. Ecosystems 2003, 6, 129-143. [CrossRef]

92. Cai, H.; Shi, B.; Geng, P.; Di, X.; Chang, S.X.; Wang, C.; Jin, G. Carbon storage, net primary production, and net ecosystem production in four major temperate forest types in northeastern China. Can. J. Res. 2016, 46, 143-151. [CrossRef]

93. Gower, S.T.; Gholz, H.L.; Nakane, K.; Galdwin, V.C. Production and carbon allocation patterns of pine forests. Ecol. Bull. 1994, 43, 115-135.

94. Gough, C.M.; Vogel, C.S.; Hardiman, B.; Curtis, P.S. Wood net primary production resilience in an unmanaged forest transitioning from early to middle succession. Ecol. Manag. 2010, 260, 36-41. [CrossRef]

95. He, H.; Pan, Y.; Zhu, W.; Liu, X.; Zhang, Q.; Zhu, X. Measurement of terrestrial ecosystem service value in China. J. Appl. Ecol. 2005, 16, 16.

96. Li, Y.P.; Ji, J.J. Simulations of carbon exchange between global terrestrial ecosystem and the atmosphere. Acta Geogr. Sin. 2001, 56, 379-389.

97. Pregitzer, K.S.; Euskirchen, E.S. Carbon cycling and storage in world forests: Biome patterns related to forest age. Glob. Chang. Boil. 2004, 10, 2052-2077. [CrossRef]

98. Wang, C.K.; Yang, J.Y. Rhizospheric and heterotrophic components of soil respiration in six Chinese temperate forests. Glob. Chang. Biol. 2010, 13, 123-131. [CrossRef]

99. Hardiman, B.S.; Bohrer, G.; Gough, C.M.; Vogel, C.S.; Curtis, P.S. The role of canopy structural complexity in wood net primary production of a maturing northern deciduous forest. Ecology 2011, 92, 1818-1827. [CrossRef]

100. Hynynen, J.; Niemistö, P.; Viheräaarnio, A.; Brunner, A.; Hein, S.; Velling, P. Silviculture of birch (Betula pendula Roth and Betula pubescens Ehrh.) in northern Europe. Forestry 2010, 83, 103-119. [CrossRef]

(C) 2019 by the authors. Licensee MDPI, Basel, Switzerland. This article is an open access article distributed under the terms and conditions of the Creative Commons Attribution (CC BY) license (http://creativecommons.org/licenses/by/4.0/). 